\title{
Supported dual-atom catalysts: Preparation, characterization, and potential applications
}

\author{
Jing Zhang a,b, Qiu-an, Huang a, Juan Wang b,\#, Jing Wang a, Jiujun Zhang a, Yufeng Zhao a,c,* \\ a Institute for Sustainable Energy/College of Sciences, Shanghai University, Shanghai 200444, China \\ b Shanxi Key Laboratory of Nanomaterials and Nanotechnology, School of Mechanical \& Electrical engineering, Xi'an University of Architecture and \\ Technology, 710055 Xi'an, Shaanxi, China \\ c Key Laboratory of Applied Chemistry, Yanshan University, Qinhuangdao 066004, Hebei, China
}

\section{A R T I C L E I N F O}

\section{Article history:}

Received 12 October 2019

Accepted 23 November 2019

Published 5 May 2020

\section{Keywords:}

Dual-atoms catalyst

Homonuclear

Heteronuclear

Electrocatalyst

Energy conversion and storage device

\begin{abstract}
A B S T R A C T
Developing sustainable and clean electrochemical energy conversion technologies is a crucial step in addressing the challenges of energy shortage and environmental pollution. Exploring and developing new electrocatalysts with excellent performance and low cost will facilitate the commercial use of these energy conversion technologies. Recently, dual-atom catalysts (DACs) have attracted considerable research interest since they exhibit higher metal atom loading and more flexible active sites compared to single-atom catalysts (SACs). In this paper, the latest preparation methods and characterization techniques of DACs are systematically reviewed. The advantages of homonuclear and heteronuclear DACs and the catalytic mechanism and identification technologies between the two DACs are highlighted. The current applications of DACs in the field of electrocatalysis are summarized. The development opportunities and challenges of DACs in the future are prospected. The ultimate goal is to provide new ideas for the preparation of new catalysts with excellent properties by customizing diatomic catalysts for electrochemical applications.
\end{abstract}

(C) 2020, Dalian Institute of Chemical Physics, Chinese Academy of Sciences. Published by Elsevier B.V. All rights reserved.

\section{Introduction}

With the further development of industrialization and the continuous increase of the global population, human society is facing an increasingly severe crisis of resource depletion and environmental degradation. The excessive consumption of fossil fuel, such as oil, coal, and natural gas, has accelerated the increasingly serious energy crisis and environmental pollution. The exploration and development of renewable and sustainable clean energy to replace fossil fuels has therefore become an important direction in the field of catalysis and energy research
[1-3]. Of particular interest are studies on fuel cells, electrolytic cells, and metal-air batteries as clean energy storage and conversion devices $[4,5]$. For conversion of electrical and chemical energy, these devices depend on electrocatalytic reactions (e.g., oxygen reduction and evolution reactions, hydrogen evolution/oxidation reactions, etc.) and charge transfer processes occurring on the electrode material. Electrocatalysts are the core components of electrode materials in such devices, and the thermodynamic and kinetic processes of electrocatalytic reactions are closely related to the physical properties and chemical states of electrocatalysts. Almost all of these electro-

\footnotetext{
* Corresponding author. E-mail: yufengzhao@shu.edu.cn

\# Corresponding author. E-mail: juanwang168@gmail.com

This work was supported by the National Natural Sciecne Foundation of China (51774251), the Hebei Science Foundation for Distinguished Young Scholars (B2017203313), Hundreds of Innovative Talents in Hebei Province (SLRC2017057), the opening project of the state key laboratory of Advanced Chemical Power Sources (SKL-ACPS-C-11), and the Talent Engineering Training Funds of Hebei Province (A201802001).

DOI: 10.1016/S1872-2067(20)63536-7 | http://www.sciencedirect.com/science/journal/18722067 | Chin. J. Catal., Vol. 41, No. 5, May 2020
} 
catalytic reactions rely heavily on the use of precious metal materials such as Pt to reduce the overpotential and accelerate the catalytic reactions, but precious-metal catalysts have drawbacks such as high price, scarce resources, and poor long-term cycle stability. Therefore, the further development of low-cost, durable electrocatalysts to effectively facilitate these electrocatalytic reactions at the cathode remains the Achilles' heel of the technology and seriously hinders its widespread implementation [6-8].

As an important catalytic system, metals have made significant contributions to energy conversion, chemical conversion, and environmental governance. Metal-based catalysts have been used in many applications, such as fuel cells, petroleum refining, emission reduction, chemical semi-finished products, and drugs and pesticides [9-12]. Such catalysts rely primarily on coordination unsaturated metal atoms on the surface of the catalyst or the interaction between metal atoms and adsorption groups in order to adsorb the reactants and intermediates, thereby completing the catalytic reactions. However, the utilization rate of metal atoms is relatively low because most catalytic reactions of metal-based catalysts occur on the metal surface, the reactant molecules cannot be close to certain metal atoms, and the coordination unsaturated metal sites located on the surface only account for a fraction of the metal components of the catalyst material. An increasing number of studies are therefore focusing on reducing the geometric size of granular catalysts in order to increase the proportion of metal centers with low coordination. The most effective method is to reduce the size of the metal to a single atom, thus making full use of each metal atom in a metal catalyst fixed by supporting substrates [13-16]. The decrease in the size of the particles also leads to other novel characteristics such as quantum size effects and interactions between the metal and the supporting substrates. This size effect is particularly evident in sub-nanometer-scale metal-cluster catalysts. Even the sub-nanometer-scale metal cluster catalysts have multiple catalytic sites. Owing the abovementioned factors, many studies have shown that reducing the size of metal particles can significantly enhance the catalytic activity of metal-based catalysts [17-24]. Theoretically, the limit of dispersion of loading metal catalysts on the supporting substrates is that the metal is evenly distributed on the supporting substrates (mainly carbon-based materials) in the form of a single atom, which not only achieves the ideal state of metal-based catalysts, but also introduces the science of catalysis to a smaller-scale, single-atomic catalysis. Thus, among these fixed metal atoms, only a single isolated single metal atom is used as the main active center, i.e., "single-atom catalysts (SACs)" [25,26]. The active center can also be an atom adjacent to these isolated single atoms, and the physicochemical properties of the fixed single metal atoms depend on their interaction with the supporting substrate material.

In 2011, Zhang and co-workers synthesized Pt single-atom catalyst loading on the surface of $\mathrm{FeO}_{x}$ by the co-precipitation method, and thus proposed the concept of SACs [27]. Subsequently, SAC synthesis based on metal-oxide supporting substrates has been extensively explored, and numerous successful examples have been demonstrated, such as $\mathrm{FeO}_{x}[14,28-33]$, $\mathrm{Cu}_{2} \mathrm{O}$ [34], $\mathrm{Al}_{2} \mathrm{O}_{3}$ [35], $\mathrm{Co}_{3} \mathrm{O}_{4}$ [36,37], $\mathrm{CeO}_{2}$ [38], and $\mathrm{MgO}$ $[39,40]$. The limit of single-atom dispersion as a metal-loading catalyst has many novel characteristics. For instance, metal atoms exhibit higher unsaturated coordination, quantum size effects, and favorable interaction between the metal and the supporting substrates. Owing to these characteristics, the single-atom central electron structure of the loading catalyst metal is different from the metal coordination of nano- or sub-nano-sized particles and thus exhibits unique catalytic activity. Owing to these excellent characteristics, SACs form a bridge between homogeneous and heterogeneous catalysts. For precious-metal catalysts, SACs greatly reduce the material cost owing to the extremely high utilization rate of metal atoms. Precious-metal SACs also have great prospects in industrial application.

However, although many remarkable achievements have been made in the field of the SACs in recent years [41-43], most of them have only been carried out in the laboratory. The further application of SACs is limited mainly because SACs only have a single active site, which makes it difficult to break linear scaling relationships between the adsorption energies of reaction intermediates, leading to a fundamental limitation to the catalytic efficiency [44-46]. Meanwhile, in order to avoid the formation of metal nanocrystals due to the large surface energy of single metal atoms, the catalyst loadings of most reported syntheses are relatively low, generally less than $1.5 \%$, resulting in a lower overall activity [47-55]. These problems pose a huge challenge to the synthetic process of the SACs. Considering the small contact area between the single atom and the supporting substrate material and the relatively weak interaction, dual atomic catalysts (DACs) have recently emerged as a further expansion to the family of SACs in order to further increase the active sites and the single-atom loading. Although research on DACs is still in the early stages, the research work reported so far has mainly focused on two aspects: homonuclear DACs and heteronuclear DACs [56-65]. Most of these studies are related to homonuclear DACs. Zeng et al. [56] demonstrated that the synergistic effect of the adjacent Pt monomers on $\mathrm{MoS}_{2}$ greatly increases the catalytic activity of $\mathrm{CO}_{2}$ hydrogenation and reduces the activation energy relative to the isolated monomers. Pt has a mass loading of 7.5\%, maintaining its atomic dispersion. Xing et al. [58] used the organic framework as a precursor to precisely synthesize a diatomic center catalyst with a highly active structure by adjusting the content of the active component Co, and thus, the active site reached 12 times that of the current SACs. Theoretical calculations show that the reaction energy barrier at this active site is greatly reduced, and the reaction kinetics is significantly accelerated during the oxygen reduction reaction (ORR) process. Lu et al. [59] reported remarkable activity of graphene-supported $\mathrm{Pt}_{2}$ dimers during the hydrogen production process of ammonia borane, which is about 17 times more active than graphene-supported single-atom $\mathrm{Pt}_{1}$.

Furthermore, studies have shown that the dual-metal $M_{1}$, $\mathrm{M}_{2}-\mathrm{N}_{x}-\mathrm{C}$ sites in macrocyclic compounds are more active than the single-center sites $[66,67]$, and the synergistic effect be- 
tween $\mathrm{M}_{1}$ and $\mathrm{M}_{2}$ in DACs can significantly improve the catalytic performance [68]. Some researches on the heteronuclear DACs have therefore gradually begun to emerge in recent years [69-75]. Chen et al. [69] proved the heteronuclear $\mathrm{Fe}_{1}-\mathrm{Cu}_{1} @ \mathrm{C}_{2} \mathrm{~N}$ DACs compared with the homonuclear $\mathrm{Fe}_{2} @ \mathrm{C}_{2} \mathrm{~N}$ and $\mathrm{Cu}_{2} @ \mathrm{C}_{2} \mathrm{~N}$ DACs exhibit excellent catalytic performance for CO oxidation, which is attributed to the fact that the center of the d-band of $\mathrm{Fe}_{1}-\mathrm{Cu}_{1} @ \mathrm{C}_{2} \mathrm{~N}$ is between $\mathrm{Fe}_{2} @ \mathrm{C}_{2} \mathrm{~N}$ and $\mathrm{Cu}_{2} @ \mathrm{C}_{2} \mathrm{~N}$, and the strength of the adsorption energy of the reactants has good correlation with the center of the d-band. This is consistent with the theory of d-band center proposed by Hammer and Nörskov [76,77]. Zhao et al. [70] revealed that Zn-Co dual atomic pairs coordinated with doped nitrogen in a carbon support ( $\mathrm{Zn} / \mathrm{Co}-\mathrm{N}-\mathrm{C})$ could enhancing the binding abilities for $\mathrm{O}_{2}$ during the ORR process, significantly elongating the $\mathrm{O}-\mathrm{O}$ length from 1.23 to $1.42 \AA$ and thus facilitating the cleavage of O-O bonds, which is vital for the $4 \mathrm{e}^{-}$pathway ORR process [73,75,78-81]. Wu et al. [71] reported host-guest design of a hollow carbon-derived material with porphyrin-like Fe-Co dual sites ( $(\mathrm{Fe}, \mathrm{Co}) / \mathrm{N}-\mathrm{C})$ and compared its ORR activity in acidic conditions against that of commercial $\mathrm{Pt} / \mathrm{C}$. As a cathode catalyst for fuel cells, the Fe-Co DAC not only reduces the cost of the fuel cell catalytic layer, but also has a maximum output power density of $0.51 \mathrm{~W} \mathrm{~cm}^{-2}$, which is $76 \%$ of commercial $\mathrm{Pt} / \mathrm{C}$ under the condition of less than $1 \mathrm{mg} \mathrm{cm}^{-2}$ loading. The excellent performance is attributed to the existence of $\mathrm{Fe}-\mathrm{Co}$ bonds, which is more conducive to the cleavage of $\mathrm{O}-\mathrm{O}$ bonds, thus making the structure highly active in ORR reaction. Zhao et al. [72] also reported host-guest design of the Ni/Fe-N-C DAC, which has higher electrocatalytic activity and higher $\mathrm{CO}$ Faraday efficiency than $\mathrm{Ni}-\mathrm{N}-\mathrm{C}$ and $\mathrm{Fe}-\mathrm{N}-\mathrm{C}$ SACs. In addition, DFT calculations showed that the diatomic sites exhibit suitable adsorption/desorption energy of $\mathrm{CO}_{2}$ and intermediates, which reduces the potential barrier of $\mathrm{CO}_{2}$ reduction and reveals the essence of its excellent electrochemical performance.

Inspired by these works, we believe that the DACs may become the target of atomic catalyst in the future, mainly because in addition to the advantages of SACs, DACs also have higher metal atomic loading and more flexible active sites (top and bridge sites) [57]. In addition, since two metal atoms that are different will constitute more heteronuclear DACs and owing to the fact that two metal atoms can cooperate with each other in the heteronuclear diatomic metal catalyst, the center position of the d-band is more effectively adjusted. Thereby, the interaction of the reactant or intermediate with the catalytically active site is optimized. In this regard, there are more possibilities for heteronuclear DACs that can be explored in the future.

\section{Synthesis and characterization technology of dual-atom catalysts}

\subsection{Synthesis strategies}

DACs, as a further extension to the family of SACs, have attracted a lot of attention by virtue of its high loading, the synergy between the two metals, and the strong interaction between the metal and the supporting substrate materials. How- ever, the preparation of highly dispersed DACs remains a key challenge due to the inevitable tendency of metal atoms to aggregate during the synthesis process. Based on the synthesis method of SACs, the currently reported methods for DACs synthesis include atomic layer deposition (ALD) [59], wet chemical adsorption [61], and high temperature heat treatment $[70,71,73]$. It is worth noting that the large-scale commercial application is limited by the high cost of ALD resulting from its requirements for equipment and processes. Based on physical and chemical adsorption, metal ions are adsorbed to the surface of the supporting substrate materials such as oxides by the wet chemical adsorption method in order to construct diatomic sites. In general, DACs synthesized by this method have low thermal stability and chemical stability. Unlike the two abovementioned mild methods, the high-temperature heat treatment method (HTHM) utilizes a higher-temperature-induced chemical reaction, such as phase transformation, decomposition, and remodeling, to transfer or decompose the precursor adsorbed on the supporting substrate materials, and further interaction with the coordinating atoms on the surface of the substrate materials to construct a coordination center of the diatomic metal catalyst. Such DACs obtained by HTHM have excellent thermal and structural stability [82-84].

We recently reported a uniformly and highly dispersed $\mathrm{Zn} / \mathrm{Co}-\mathrm{N}_{x}-\mathrm{C}$ diatomic high efficiency oxygen reduction catalyst prepared by HTHM (Fig. 1(a)) based on competitive coordination strategy. The characterization of high-angle annular dark field scanning transmission electron microscopy (HAADF-STEM) (Figs. 1(b) and (c)) combined with X-ray absorption fine structure spectroscopy (XAFS) confirmed that the

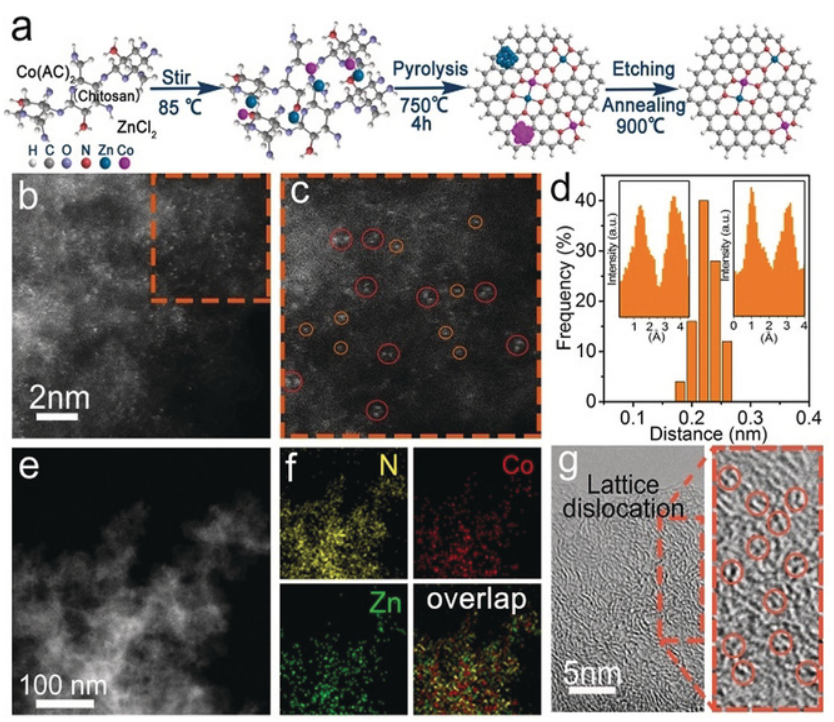

Fig. 1. (a) Illustration of the formation of $\mathrm{Zn} / \mathrm{Co}-\mathrm{N}-\mathrm{C}$. (b) Aberration-corrected HAADF-STEM image and (c) enlarged images of the $\mathrm{Zn} / \mathrm{Co}-\mathrm{N}-\mathrm{C}$. In (c), some of bimetallic $\mathrm{Zn} /$ Co sites are highlighted by larger red circles, and some of single $\mathrm{Co} / \mathrm{Zn}$ atoms highlighted by smaller orange circles. (d) Statistical Zn-Co distance in the observed diatomic pairs, in which the two insets are intensity profiles obtained on two bimetallic Co/Zn sites. (e) HAADF-STEM image and (f) corresponding element maps, showing the distribution of $\mathrm{N}, \mathrm{Zn}$, and Co. (g) HR-TEM image of $\mathrm{Zn} / \mathrm{Co}-\mathrm{N}-\mathrm{C}$, in which some lattice distortions are highlighted by orange circles. Reproduced with permission [70]. 
$\mathrm{Zn}$-Co diatomic pair exists as $\mathrm{ZnCoN}_{6}$. Density functional theory (DFT) calculations indicated that the $\mathrm{ZnCoN}_{6}$ diatomic pair can significantly increase the $0-0$ bond from the original 1.23 to $1.42 \AA$, which is beneficial to the cleavage of $\mathrm{O}-\mathrm{O}$ bond (Fig. 1(d)). In particular, HAADF-STEM (Figs. 1(e)) and elemental mapping (Fig. 1(f)) reveal that N, Zn, and Co are homogeneously distributed in the Zn/Co-N-C. The HR-TEM image (Fig. 1(g)) demonstrates lattice distortion defects characteristics, which might be attributed to the coordination of single or dual $\mathrm{Zn} / \mathrm{Co}$ atoms with nitrogen. Theoretical calculations and in-situ XANES tests further confirmed that a Co atom is the active center of the $\mathrm{ZnCoN}_{6}$ diatomic structure, and the structure remained stable after long-cycle testing. The synthesis strategies provide a reference for the mass preparation of DACs with high activity. In addition, the combination of detailed characterization and theoretical calculation provides a deeper understanding of the origin of the DAC activity, and has important significance in guiding the synthesis and mechanism discussion of other electrocatalytic catalysts [70].

It can be seen that the supporting substrate materials play a crucial role in the remarkable performance of the DACs. It is crucial to determine the influence of the structure, modification, and functionalization of the supporting substrate materials on the surface of the substrate materials in order to understand the preparation and formation mechanism of diatomic catalysts. There are many reports on the design of $\mathrm{N}$-doped carbon as the supporting material for dual metal sites, among which the " $-\mathrm{C}_{2} \mathrm{~N}$ " architecture is quite popular. As reported, the $\mathrm{N}$ atom located in the " $-\mathrm{C}_{2} \mathrm{~N}$ " hole has a lone pair of electrons, and the transition group non-precious-metal atoms $(\mathrm{Cr}, \mathrm{Mn}, \mathrm{Fe}$, $\mathrm{Co}, \mathrm{Ni}$ ) can be anchored in the " $-\mathrm{C}_{2} \mathrm{~N}$ " hole, which makes diffusion difficult in thermodynamics and dynamics, thus avoiding the agglomeration of metal atoms and resulting in outstanding stability $[57,60]$. The $\mathrm{Mn}_{2}-\mathrm{C}_{2} \mathrm{~N}$ has stronger activation effect on nitrogen for nitrogen reduction catalytic reactions $\left(\mathrm{Mn}_{2}-\mathrm{C}_{2} \mathrm{~N}\right.$ is more strongly adsorbed to the intermediate state of $\mathrm{NNH}^{*}$, which is conducive to the first hydrogenation of nitrogen). The catalytic activity of $\mathrm{Mn}_{2}-\mathrm{C}_{2} \mathrm{~N}$ was significantly higher than that of $\mathrm{Mn}-\mathrm{C}_{2} \mathrm{~N}(-0.23 \mathrm{~V}$ vs. RHE), which is the best reported value thus far. It is pointed out that DACs can replace SACs and become the best choice for nitrogen reduction catalytic reaction, which provides a new idea for catalyst design of nitrogen reduction catalytic reaction [57].

Furthermore, "graphitic carbon nitride $\left(\mathrm{g}-\mathrm{C}_{3} \mathrm{~N}_{4}\right)$ " is also popular because it contains a large number of "Pyridinic-N", which provides many lone-pair electrons to capture metal ions. Wang et al. [61] reported a "precursor-preselected" wet-chemistry strategy to synthesize highly dispersed $\mathrm{Fe}_{2}$ clusters that are supported on mesoporous carbon nitride (mpg- $\mathrm{C}_{3} \mathrm{~N}_{4}$ ). The obtained $\mathrm{Fe}_{2} / \mathrm{mpg}-\mathrm{C}_{3} \mathrm{~N}_{4}$ sample exhibits superior catalytic performance for the epoxidation of trans-stilbene to trans-stilbene oxide, showing outstanding selectivity of $93 \%$ at high conversion of $91 \%$. In contrast, under the same condition, iron porphyrin, single-atom $\mathrm{Fe}$, and small Fe nanoparticles (ca. $3 \mathrm{~nm}$ ) are almost reactively inert. First-principles calculations reveal that the unique reactivity of the $\mathrm{Fe}_{2}$ clusters originates from the formation of active oxygen species. The general applicability of the synthesis approach is further demonstrated by producing other diatomic clusters such as $\mathrm{Pd}_{2}$ and $\mathrm{Ir}_{2}$, which lays the foundation for discovering diatomic cluster catalysts. It is worth noting that the drawback of " $\mathrm{g}-\mathrm{C}_{3} \mathrm{~N}_{4}$ " is the poor electronic conductivity, so it is often combined with carbon carriers such as carbon nanotubes and graphene to enhance the charge transfer and electrocatalytic activity.

The selection of the synthesis methods and the supporting substrate materials are very crucial to the performance of DACs. Nevertheless, there are some unavoidable shortcomings in many reported DACs, such as the low proportion of dual atoms in the catalysts with single/dual-atom co-existence. As both the single- and dual-atom sites are thermodynamically stable, it is hard to control the proportion between single- and dual-atoms experimentally. The following approaches maybe helpful for manipulating the dual-atom sites: (a) Improvement on the synthetic technique; (b) careful adjustment of the proportion between the metallic precursors and synthetic procedures, and (c) optimization of the substrate architecture so that it can provide more suitable energy barriers for dual-atom sites.

\subsection{Characterization technology}

The active site acts as the center of the catalyst, and its properties are crucial in the performance of the catalyst. The identification of the active site will help us gain a deeper understanding of the reaction mechanism occurring on the catalyst surface, which will provide strategies for further rational design of catalysts [85-89]. Compared with SACs, the metal sites in DACs are dispersed on the supporting substrate materials at the diatomic level, and hence, there is still some controversy about the identification of bimetallic sites in homonuclear and heteronuclear DACs. The high-resolution scanning transmission electron microscope (HRSTEM) with spherical aberration correction has become one of the main tools to detect metal dual-atoms sites because of its subatomic structure resolution. The brightness of atoms is proportional to the square of their atomic number in the atomic-scale resolution images obtained by a high-angle ring dark field detector [90]. The existence, composition, and distribution of atoms on the surface of the catalyst can also be observed by the combination of atomic resolution scanning tunneling microscope (STM) and energy-dispersive X-ray spectroscopy (EDS). In addition, the absorption spectroscopy based on synchrotron radiation can not only provide the statistical average results of information about metal dual-atoms, but also further reveal the chemical valence state and coordination environment of the metal dual-atoms. The absorption spectroscopic characterization methods based on synchrotron radiation mainly include X-ray absorption near edge structure (XANES) and extended X-ray absorption fine structure (EXAFS) [91]. The different X-ray energies used can be subdivided into soft light and hard light [92,93]. Further fitting and analysis of the results of the hard $\mathrm{X}$-ray synchrotron radiation absorption spectroscopy can provide the electronic filling state of the central metal, the coordi- 
nation environments of the surrounding atoms, and the bonding state conditions of the DACs. In particular, the characterization of synchrotron radiation absorption spectroscopy based on soft light can further provide important information on the electronic structure and chemical valence states of the metal dual-atoms on the catalyst surface. In addition, quantum chemistry and molecular simulation have become important techniques in the field of catalysis owing to the current high-performance computing technology. Infrared (IR) spectroscopy has also been widely used in the study of surface properties of catalysts, which is a method to identify substances and determine their chemical composition, structure or relative content by using the absorption characteristics of substances to infrared radiation of different wavelengths [94,95]. Because the atoms that make up chemical bonds or functional groups are in the state of constant vibration, their vibration frequencies are equal to that of infrared light, so when the sample is irradiated by infrared light, the chemical bonds or functional groups in the molecules may absorb vibration, resulting in energy level transition. Different chemical bonds or functional groups have different absorption frequencies and will be at different positions in the infrared spectrum, and thus, the information of which chemical bonds or functional groups are contained in the molecules can be obtained. This method is very significant for revealing the catalytic reaction mechanism. Density functional theory (DFT) has played a significant role in the research of DACs. It can effectively simulate and calculate the atomic structure, electronic structure, reaction path, and intermediate state process of active sites [96,97]. For example, the rationality of atomic active site structure can be verified by comparing the bond length with experimental data via relaxation optimization of the model structure. According to the calculation of bond energy, electron transfer number, bond lengths, and other parameters of the dual-atoms at different adsorption sites, the most favorable adsorption sites can be determined through comparison with experimental data. The most favorable reaction path can be determined by simulating the adsorption of reaction molecules, the more possible reaction path, and the formation energy of intermediate products, and the reaction mechanism can be preliminarily explored. DFT calculation has been widely used in DACs as an important means to study the microstructure and reaction mechanism of chemical systems. It not only deepens the understanding of the microstructures and reaction kinetics of the active sites of catalysts at atomic and electronic levels, but also provides an effective theoretical basis for the further design of new efficient and stable DACs. The present reported work further confirms the existence of dual atoms and the corresponding valuable information by characterizing the relative morphology and structure analysis and by combining DFT calculations. Some common DAC characterization techniques to study the catalytic activity sites and molecular structure activity/selectivity relationship are listed above. In fact, owing to the complexity of metal dual-atom interaction in DACs, it is still necessary to explore how to obtain the reaction essence of the DACs by characterization technology, sequentially providing theoretical guidance for the rational design, and development of efficient and stable DACs.

\section{Electrocatalytic application of dual-atom catalysts}

DACs exhibit remarkable catalytic activity in a series of catalytic reactions owing to their high loading, synergy between two metals, and strong interaction between the metals and the supporting substrates materials. In addition, the special geometry and electronic structure between the two metals in DACs allow some reactions to show different catalytic selectivity from conventional nanoparticles. Reported works on DACs have mainly applied ORR [58,70,71,73-75] and $\mathrm{CO}_{2}$ reduction reaction $\left(\mathrm{CO}_{2} \mathrm{RR}\right)[60,63-65,72]$, (Tables 1 and 2). We discuss some recent examples in order to demonstrate the catalytic capacity and great potential of DACs.

\subsection{Oxygen reduction reaction}

Hydrogen-oxygen fuel cell is a new energy technology that is clean, efficient, safe, and environmentally friendly. Fuel cell vehicles are an important development direction of new energy vehicles in China. Cathode ORR is one of the core catalytic reactions of fuel cells [102-108]. Common ORR reactions mainly include the following three pathways: (a) the "direct" four-electron reaction path is reduced to $\mathrm{H}_{2} \mathrm{O}$ (acidic medium) or $\mathrm{OH}$ - (alkaline medium); (b) reduction of the two-electron reaction pathway to generate hydrogen peroxide; (c) a series of reactions in which "two electrons" and "four electrons" coexist. Many intermediates (such as $\mathrm{O}^{*}, \mathrm{OOH}^{*}, \mathrm{OH}^{*}$ ) are produced during oxygen reduction, and their adsorption on the electrode

\section{Table 1}

The main directions of current applications of DAC electrocatalysis.

\begin{tabular}{|c|c|c|c|c|}
\hline & Materials & Substrate & Application & Ref. \\
\hline \multirow{10}{*}{$\begin{array}{l}\text { The } \\
\text { homo- } \\
\text { nuclear } \\
\text { DACs }\end{array}$} & $\mathrm{Cu}_{2} \mathrm{C}_{2} \mathrm{~N}$ & $\mathrm{C}_{2} \mathrm{~N}$ & $\mathrm{CO}_{2} \mathrm{RR}$ & [60] \\
\hline & $\begin{array}{c}\mathrm{XY} @ 2 \mathrm{SV} \text { a } \\
\left(\mathrm{XY}=\mathrm{Cu}_{2}, \mathrm{CuMn}, \mathrm{CuNi}\right)\end{array}$ & graphene & $\mathrm{CO}_{2} \mathrm{RR}$ & [63] \\
\hline & $\mathrm{Mn}_{2}-\mathrm{Pc}^{\mathrm{b}}$ & Pc & $\mathrm{CO}_{2} \mathrm{RR}$ & [64] \\
\hline & $\begin{array}{c}\mathrm{Cu}-\mathrm{APC} / \mathrm{Pd}_{10} \mathrm{Te}_{3} \text { nan- } \\
\text { owires }^{\mathrm{c}}\end{array}$ & $\begin{array}{c}\mathrm{Pd}_{10} \mathrm{Te}_{3} \\
\text { nanowires }\end{array}$ & $\mathrm{CO}_{2} \mathrm{RR}$ & [65] \\
\hline & $\mathrm{Co}-\mathrm{N}-\mathrm{C}$ & $\mathrm{N}-\mathrm{C}$ & ORR & [58] \\
\hline & $\begin{array}{c}\mathrm{TM}_{2}-\mathrm{C}_{2} \mathrm{~N} \\
(\mathrm{M}=\mathrm{Cr} / \mathrm{Mn} / \mathrm{Fe} / \mathrm{Co} / \mathrm{Ni})\end{array}$ & $\mathrm{C}_{2} \mathrm{~N}$ & NRR & [57] \\
\hline & $\mathrm{Pt}_{2} /$ graphene & graphene & $\begin{array}{l}\text { The hydrolytic de- } \\
\text { hydrogenation } \\
\text { of ammonia borane }\end{array}$ & [59] \\
\hline & $\mathrm{Fe}_{2} / \mathrm{mpg}-\mathrm{C}_{3} \mathrm{~N}_{4}{ }^{\mathrm{d}}$ & mpg- $\mathrm{C}_{3} \mathrm{~N}_{4}$ & $\begin{array}{l}\text { The epoxidation of } \\
\text { trans-stilbene to } \\
\text { trans-stilbene oxide }\end{array}$ & [61] \\
\hline & adjacent $\mathrm{Pt} / \mathrm{MoS}_{2}$ & $\mathrm{MoS}_{2}$ & $\mathrm{CO}_{2}$ hydrogenation & [56] \\
\hline & DiFe@TV_2 e & graphene & - & [62] \\
\hline \multirow{7}{*}{$\begin{array}{l}\text { The } \\
\text { hetero- } \\
\text { nuclear } \\
\text { DACs }\end{array}$} & $\mathrm{Zn} / \mathrm{CoN}-\mathrm{C}$ & $\mathrm{N}-\mathrm{C}$ & ORR & [70] \\
\hline & $(\mathrm{Fe}, \mathrm{Co}) / \mathrm{N}-\mathrm{C}$ & $\mathrm{N}-\mathrm{C}$ & ORR & [71] \\
\hline & $(\mathrm{Fe}, \mathrm{Co}) / \mathrm{CNT}$ & CNT & ORR & [75] \\
\hline & $\mathrm{Ni} / \mathrm{Fe}-\mathrm{N}-\mathrm{C}$ & $\mathrm{N}-\mathrm{C}$ & $\mathrm{CO}_{2} \mathrm{RR}$ & [72] \\
\hline & $\mathrm{Co} / \mathrm{Ni}-\mathrm{N}-\mathrm{C}$ & $\mathrm{N}-\mathrm{C}$ & ORR/OER & [73] \\
\hline & CuCo@N-C & $\mathrm{N}-\mathrm{C}$ & ORR/HER & [74] \\
\hline & $\mathrm{Fe}_{1} \mathrm{Cu}_{1} @ \mathrm{C}_{2} \mathrm{~N}$ & $\mathrm{C}_{2} \mathrm{~N}$ & CO oxidation & [69] \\
\hline
\end{tabular}

a SV: single vacancies; ${ }^{\mathrm{b}} \mathrm{Pc}$ : porous covalent organic frameworks; ${ }^{\mathrm{c}} \mathrm{APC}$ : atom-pair catalyst; d mpg: mesoporous carbon nitride; e DiFe@TV: Fe dimer-graphene trivacancy complex structure. 
Table 2

Comparison of the typical and highest electrochemical performances of single-atom catalysts, dual-atom catalysts, cluster catalysts, and nanoparticle catalysts for ORR and $\mathrm{CO}_{2} \mathrm{RR}$.

\begin{tabular}{|c|c|c|c|c|c|}
\hline \multicolumn{2}{|c|}{ Catalysts } & $\begin{array}{c}\text { Half-wave } \\
\text { potential } \\
\text { (V vs. RHE) }\end{array}$ & $\begin{array}{c}\text { Onset } \\
\text { potential } \\
\text { (V vs. RHE) }\end{array}$ & $\begin{array}{c}\text { Limiting } \\
\text { current density } \\
\left(\mathrm{mA} \mathrm{cm}^{-2}\right)\end{array}$ & Ref. \\
\hline \multirow{13}{*}{ ORR } & $\mathrm{Zn} / \mathrm{CoN}-\mathrm{C}$ & 0.861 & 1.004 & 6.1 & \multirow{3}{*}{70} \\
\hline & CoN-C & 0.793 & 0.872 & 4.7 & \\
\hline & $\mathrm{ZnN}-\mathrm{C}$ & 0.706 & 0.801 & 4.4 & \\
\hline & $(\mathrm{Fe}, \mathrm{Co}) / \mathrm{CNT}$ & 0.954 & 1.15 & 5.5 & \multirow{4}{*}{75} \\
\hline & Co/CNT-C & 0.786 & 0.921 & 5.2 & \\
\hline & Fe/CNT-C & 0.794 & 0.932 & 5.4 & \\
\hline & FeCo NPs/CNT & 0.895 & 1.08 & 5.4 & \\
\hline & $(\mathrm{Fe}, \mathrm{Co}) / \mathrm{N}-\mathrm{C}$ & 0.863 & 1.06 & 5.7 & \multirow{3}{*}{71} \\
\hline & Co SAs/N-C & 0.747 & 0.921 & 3.4 & \\
\hline & $\mathrm{Fe} \mathrm{SAs} / \mathrm{N}-\mathrm{C}$ & 0.747 & 0.983 & 5.5 & \\
\hline & (Cu,Co)@NC & 0.884 & 0.963 & 5.5 & \multirow{3}{*}{74} \\
\hline & Co@NC & 0.827 & 0.912 & 4.1 & \\
\hline & $\mathrm{Cu} @ N C$ & 0.734 & 0.894 & 2.8 & \\
\hline \multicolumn{2}{|c|}{ Catalysts } & $\begin{array}{l}\text { Elec- } \\
\text { trolyte }\end{array}$ & $\begin{array}{c}\text { Over } \\
\text { potential } \\
\text { (V vs. RHE) }\end{array}$ & Selectivity & Ref. \\
\hline \multirow{11}{*}{$\mathrm{CO}_{2} \mathrm{RI}$} & $\begin{array}{c}\mathrm{Ni} / \mathrm{Fe}-\mathrm{N}- \\
\mathrm{C}\end{array}$ & $0.5 \mathrm{M}$ & $\sim 0.70$ & $\mathrm{CO}(98 \%)$ & {$[72]$} \\
\hline & $\mathrm{Ni}-\mathrm{N}-\mathrm{C}$ & $\mathrm{KHCO}_{3}$ & $\sim 0.80$ & $\mathrm{CO}(90 \%)$ & \\
\hline & $\mathrm{Fe}-\mathrm{N}-\mathrm{C}$ & & $\sim 0.50$ & CO $(89 \%)$ & \\
\hline & $\mathrm{Bi}-\mathrm{Sn} / \mathrm{CF}$ & & $\sim 1.14$ & $\begin{array}{c}\text { Formate } \\
(96 \%)\end{array}$ & \multirow[t]{3}{*}[98]{} \\
\hline & $\mathrm{Sn} / \mathrm{CF}$ & $\begin{array}{c}0.5 \mathrm{M} \\
\mathrm{KHCO}_{3}\end{array}$ & $\sim 1.14$ & $\begin{array}{c}\text { Formate } \\
(80 \%)\end{array}$ & \\
\hline & $\mathrm{Bi} / \mathrm{CF}$ & & $\sim 1.14$ & $\begin{array}{c}\text { Formate } \\
(78 \%)\end{array}$ & \\
\hline & $\mathrm{FL}-\mathrm{Pd}_{3} \mathrm{Cu}$ & $0.1 \mathrm{M}$ & $\sim 0.70$ & $\mathrm{CO}(68 \%)$ & \multirow[t]{2}{*}[99]{} \\
\hline & $\mathrm{RD}-\mathrm{Cu}_{3} \mathrm{Pd}$ & $\mathrm{KHCO}_{3}$ & $\sim 1.20$ & $\mathrm{CH}_{4}(40 \%)$ & \\
\hline & & $0.5 \mathrm{M}$ & & & {$[10$} \\
\hline & $\mathrm{Cu}$ foil & $\begin{array}{c}\mathrm{Na-} \\
\mathrm{HCO}_{3}\end{array}$ & $\sim 1.17$ & $\mathrm{CH}_{4}(42 \%)$ & 0] \\
\hline & $\begin{array}{c}\mathrm{Pd}_{85} \mathrm{Cu}_{15} / \\
\mathrm{C}\end{array}$ & $\begin{array}{c}0.1 \mathrm{M} \\
\mathrm{KHCO}_{3}\end{array}$ & $\sim 0.60$ & CO (64\%) & $\begin{array}{c}{[10} \\
1]\end{array}$ \\
\hline
\end{tabular}

surface is a key step in ORR kinetics [109]. Ideal catalysts should have appropriate binding energy with reaction intermediates. According to the volcanic relationship between the oxygen reduction activity on the surface of some metal electrodes and reaction intermediates (such as $\mathrm{O}^{*}, \mathrm{OOH}^{*}, \mathrm{OH}^{*}$ ), it is obvious that the electrocatalytic activity of the precious metal $\mathrm{Pt}$ is superior to that of other precious metals [110]. However, the scarcity of Pt resources and its high cost as well as the kinetic inertia of ORR severely limit the further development of energy devices. In order to solve these problems, reducing the activity species of the catalyst from the particles to the atomic scale is an effective strategy for improving the catalyst performance. Designing DACs at the atomic scale not only overcomes the drawback of low SAC loading, but also utilizes the strong interaction between the double-metal atoms and the supporting substrates material that enhances the intrinsic activity of the active sites. In addition, the synergy between the metal diatoms has a great auxiliary advantage for the rupture of the 0-0 bond.
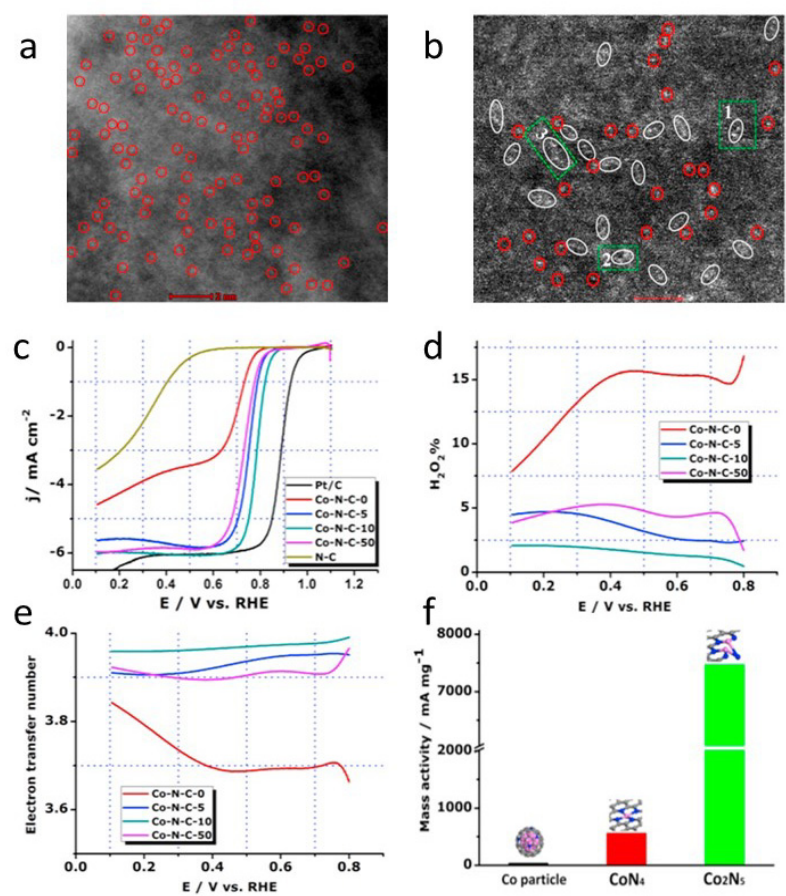

Fig. 2. (a) Aberration-corrected HAADF-STEM image of Co-N-C-50. (b) Aberration-corrected HAADF-STEM image of $\mathrm{Co}-\mathrm{N}-\mathrm{C}-10$. (c) ORR polarization curves for $\mathrm{Co}-\mathrm{N}-\mathrm{C}-\mathrm{X}, \mathrm{N}-\mathrm{C}$ and commercial $\mathrm{Pt} / \mathrm{C}$ catalysts in $\mathrm{O}_{2}$-saturated $0.1 \mathrm{M} \mathrm{HClO}_{4}$. (d) Hydrogen peroxide yield and (e) corresponding electron transfer number during ORR process for the synthesized catalysts. (f) Comparison of mass-specific activity of each active site structure. Reproduced with permission [58].

Xing et al. [58] used the metal-organic framework (MOF) as a precursor to precisely prepare a diatomic central catalyst with a highly active structure by adjusting the content of the active component $\mathrm{Co}$ under the conditions of $\mathrm{Co}-\mathrm{N}-\mathrm{C}-10$. The existence of the central active site structure of diatomic Co was confirmed by spherical aberration correction electron microscopy (ACEM) and extended X-ray absorption near-edge spectroscopy (EXANES) (Figs. 2(a) and (b)). The linear sweep voltammetry results (Fig. 2(c)) reveal that the $\mathrm{N}-\mathrm{C}$ material exhibits negligible activity for ORR compared with the Co- $\mathrm{N}-\mathrm{C}-x$ catalysts. The RRDE measurements demonstrate that the yield of $\mathrm{H}_{2} \mathrm{O}_{2}$ is suppressed on $\mathrm{Co}-\mathrm{N}-\mathrm{C}-10$, which is as low as $2 \%$ over the scanned potential range, much lower than that on Pt/C (Fig. 2(d)). The corresponding electron transfer number also reveals a four-electron pathway (Fig. 2(e)). Finally, the activity is increased by more than one order of magnitude and reaches 12 times the current single-atom active site catalyst (Fig. 2(f)), which has great practical significance. Theoretical calculations show that the reaction energy barrier of the ORR process is greatly reduced, and the reaction kinetics is significantly accelerated at this active site. In this work, the advantages of diatomic active centers are confirmed theoretically and experimentally for the first time, and this opens up new ideas for designing efficient non-precious-metal catalysts.

Wu et al. [71] use zinc-cobalt bimetallic MOF as the precursor to adsorb iron salts by double-solvent method. Under high temperature environment, $\mathrm{Fe}^{3+}$ was gradually reduced by sur- 


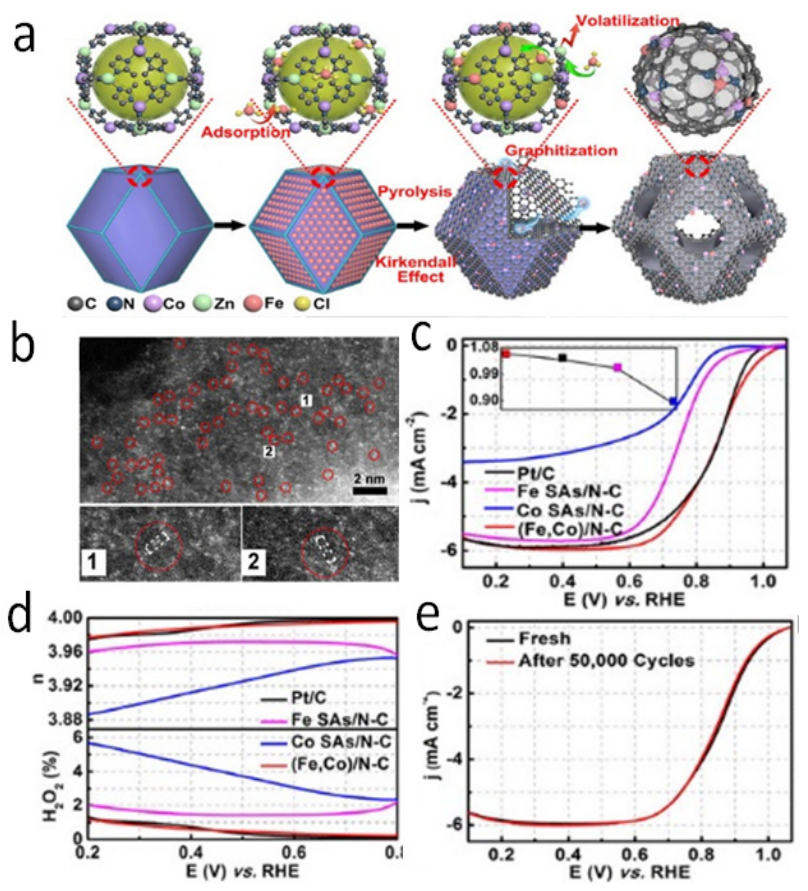

Fig. 3. (a) Preparation of (Fe, Co)/N-C. (b) Magnified HAADF-STEM of (Fe, Co)/N-C, showing Fe-Co dual sites dominant in (Fe, Co)/N-C. (c) $\mathrm{RDE}$ polarization curves of $\mathrm{Pt} / \mathrm{C}$, Co $\mathrm{SAs} / \mathrm{N}-\mathrm{C}, \mathrm{Fe} \mathrm{SAs} / \mathrm{NC}$, and (Fe, $\mathrm{Co} / \mathrm{N}-\mathrm{C}$ in $\mathrm{O}_{2}$-saturated $0.1 \mathrm{M} \mathrm{HClO}_{4}$, inset: $E_{\text {onset }}$ of different catalysts. (d) Electron transfer number (n) (top) and $\mathrm{H}_{2} \mathrm{O}_{2}$ yield (bottom) vs. potential. (e) RDE polarization curves of $(\mathrm{Fe}, \mathrm{Co}) / \mathrm{N}-\mathrm{C}$ before and after 50,000 potential cycles ranging from 0.6 to $1.0 \mathrm{~V}$ (vs. RHE) in $\mathrm{O}_{2}$-saturated $0.1 \mathrm{M} \mathrm{HClO}_{4}$. Reproduced with permission [71].

rounding graphitized $\mathrm{C}$ and bonded with adjacent $\mathrm{Co}$, thus forming the bimetallic active site of Fe and Co. Fe catalytic support generates nitrogen-doped graphitized carbon; decomposes and releases the fragments of $\mathrm{C}$ and $\mathrm{N}$, accelerating the cleavage of the metal-imidazole-metal bond; and forces the formation of voids in MOF. Eventually, a hollow structure is formed under the Kirkedall influence (Fig. 3(a)). Through spherical aberration electron microscopy, synchrotron radiation, Mossbauer spectroscopy, and other means, the diatomic material is found to contain Fe-Co bonds and coordinate with the surrounding N (Fig. 3(b)). Theoretical calculation results show that the existence of $\mathrm{Fe}-\mathrm{Co}$ bond is more conducive to the cleavage of $\mathrm{O}-\mathrm{O}$ bond, which makes the catalyst highly active in ORR. The $E_{1 / 2}$ was $0.863 \mathrm{~V}$ and the $E_{\text {onset }}$ was $1.06 \mathrm{~V}$ in the acidic ORR (Fig. 3(c)). Similar to the catalytic behavior of $\mathrm{Pt} / \mathrm{C}, \mathrm{H}_{2} \mathrm{O}_{2}$ yields with the best (Fe, Co)/ $\mathrm{N}-\mathrm{C}$ were always below $1.17 \%$ over the potential range 0.2 to $0.8 \mathrm{~V}$ (Fig. 3(d)), demonstrating almost complete avoidance of the less efficient two-electron reaction to peroxide. The current density was $2.842 \mathrm{~mA} \mathrm{~cm}^{-2}$ at $0.9 \mathrm{~V}$, and the excellent performance for 50,000 cycles was observed (Fig. 3(e)).

\section{2. $\mathrm{CO}_{2}$ reduction reaction}

Compared with traditional $\mathrm{CO}_{2}$ reduction technology, electrocatalysis has the potential to promote the transfer of elec- trons in order to achieve $\mathrm{CO}_{2}$ catalytic conversion under mild conditions. However, when an aqueous solution is used as an electrolyte, hydrogen protons in the solution are susceptible to electron transfer to generate $\mathrm{H}_{2}$, which becomes the main side reaction in electrocatalytic $\mathrm{CO}_{2} \mathrm{RR}$ and considerably restricts the process efficiency. Therefore, the design of catalysts with excellent performance to reduce overpotential and improve the reaction selectivity and stability has become the focus of $\mathrm{CO}_{2}$ electrocatalytic reduction research. DACs have the highest diatomic utilization and a large number of active centers for unsaturated coordination, which can facilitate catalyst activity [111-113]. Owing to the unique geometric and electronic properties of the DACs, the binding energy of active intermediates (such as ${ }^{*} \mathrm{COOH},{ }^{*} \mathrm{OCHO}$, etc.) in the $\mathrm{CO}_{2}$ reduction process can be significantly enhanced, thus promoting selective reduction of $\mathrm{CO}_{2}$. The adsorption energy of *H species was weakened, and the side reaction of hydrogen evolution was inhibited effectively [114]. Therefore, The DACs exhibit great potential in the high efficient electrocatalytic reduction of $\mathrm{CO}_{2}$.

Zhao et al. [72] successfully synthesized Ni-Fe diatomic catalysts based on the ZIF-8 template by the host-guest method (Fig. 4(a)). Based on the prepared catalytic materials, the electrocatalytic performance of carbon dioxide was further investigated. The results show that $\mathrm{Ni} / \mathrm{Fe}-\mathrm{N}-\mathrm{C}$ of the diatomic sites has higher electrocatalytic activity (Fig. 4(b)) and higher CO Faraday efficiency (up to $98 \%$ at -0.7 V) (Fig. 4(c)), excellent catalytic stability for more than $30 \mathrm{~h}$ ) (Fig. 4(d)), and higher catalytic activity (TOF, $7682 \mathrm{~h}^{-1}$ ) (Fig. 4(e)) than Ni-N-C and $\mathrm{Fe}-\mathrm{N}-\mathrm{C}$ of the single-atomic sites. From the DFT calculation, the
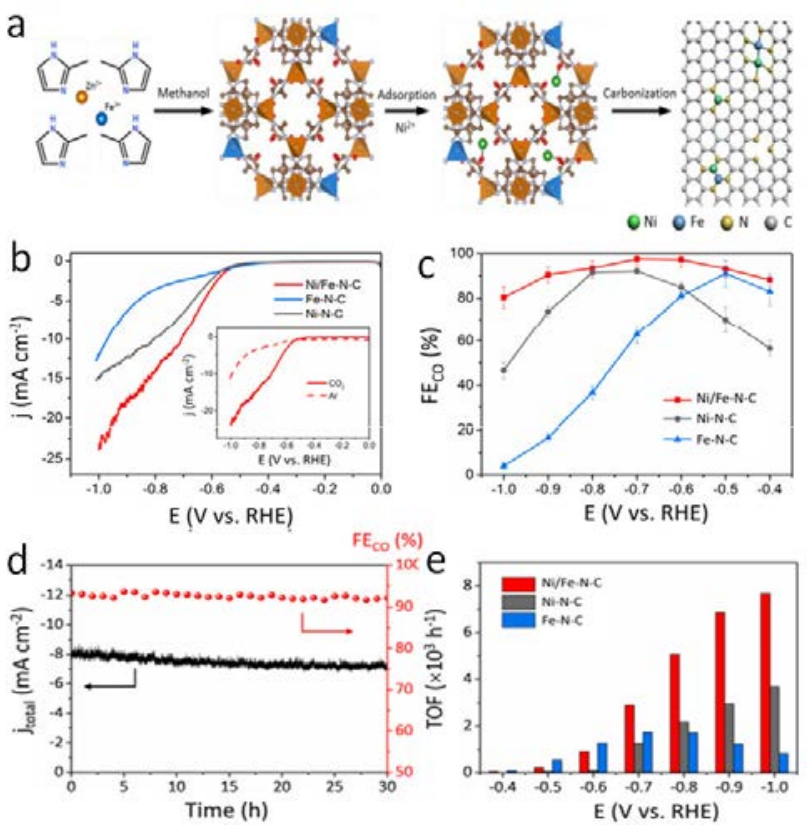

Fig. 4. (a) Schematic of the synthesis of Ni/Fe-N-C. (b) LSV curves obtained in $\mathrm{CO}_{2}$-saturated $0.5 \mathrm{M} \mathrm{KHCO}_{3}$ solution. Inset is the LSV comparison for $\mathrm{Ni} / \mathrm{Fe}-\mathrm{N}-\mathrm{C}$ in $\mathrm{Ar}$ - and $\mathrm{CO}_{2}$-saturated $0.5 \mathrm{M} \mathrm{KHCO}_{3}$ solution. (c) $\mathrm{FEco}$ of Ni/Fe-N-C, Ni-N-C, Fe-N-C at various applied potentials. (d Stability test for Ni/Fe-N-C at -0.7 V. (e) TOF of Ni/Fe-N-C, Ni-N-C, $\mathrm{Fe}-\mathrm{N}-\mathrm{C}$ at various applied potentials. Reproduced with permission [72]. 


\section{a}
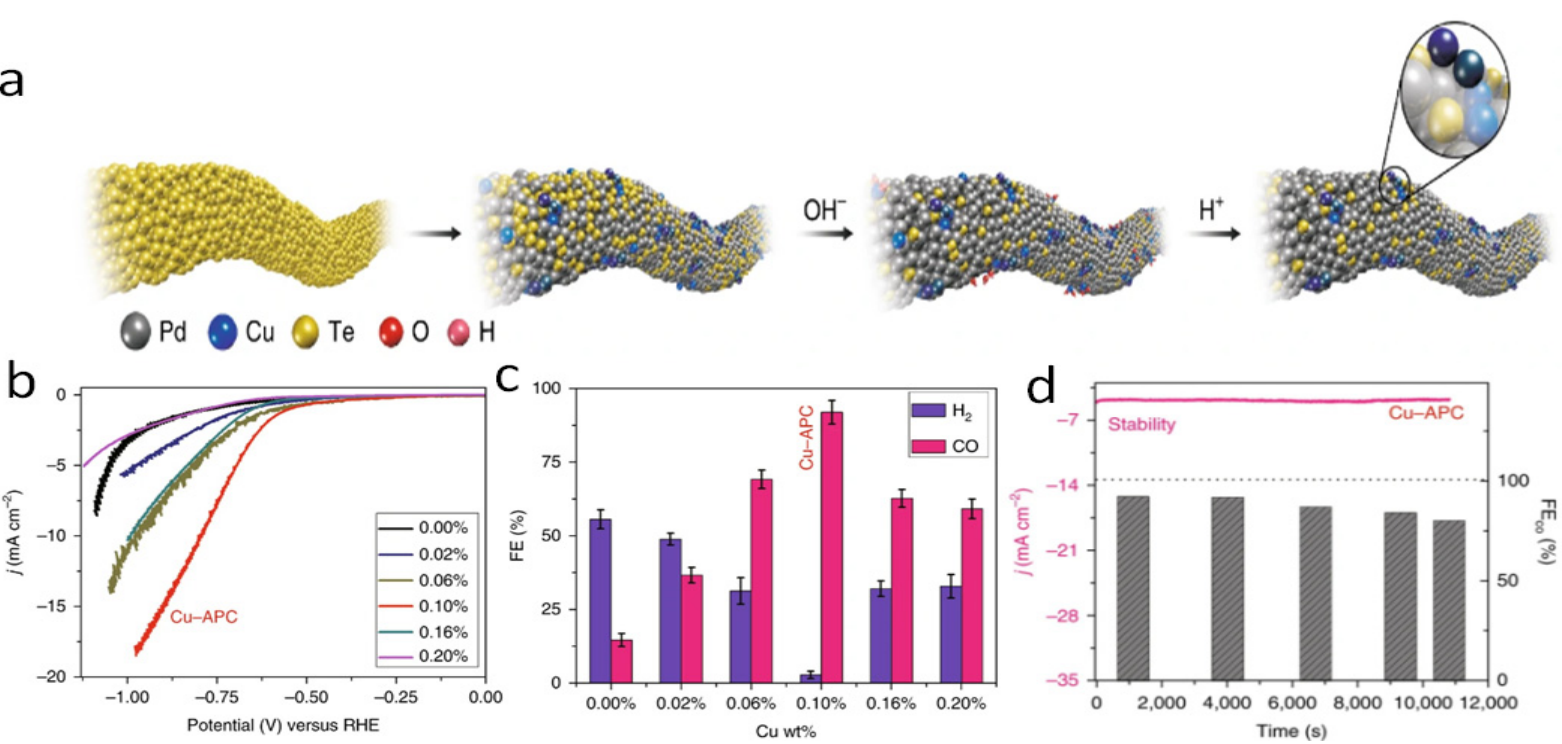

Fig. 5. (a) Schematic illustration of the fabrication procedures of atom-pair structured $\mathrm{Cu}$ anchored on $\mathrm{Pd}_{10} \mathrm{Te}_{3}$ nanowires. (b) Current-voltage curves for different samples from linear sweep voltammetry scans. (c) $\mathrm{FE}_{\mathrm{co}}$ and $\mathrm{FE}_{\mathrm{H} 2}$ of different $\mathrm{Cu}$-loaded samples at $-0.78 \mathrm{~V}$ (versus RHE). (d) Long-term durability and corresponding $\mathrm{FE}_{\mathrm{co}}$ of $\mathrm{Pd}_{10} \mathrm{Te}_{3}$ nanowires with $0.10 \mathrm{wt} \% \mathrm{Cu}(\mathrm{Cu}-\mathrm{APC})$. Reproduced with permission [65].

diatomic sites showed appropriate adsorption/desorption energy of $\mathrm{CO}_{2}$ and intermediates, which reduced the potential barrier of $\mathrm{CO}_{2}$ reduction and revealed the essence of its excellent electrochemical performance.

Xiao et al. [65] reported a strategy to construct a $\mathrm{Cu}$ atom-pair sites anchored on $\mathrm{Pd}_{10} \mathrm{Te}_{3}$ alloy nanowires (Fig. 5(a)). At the optimal $\mathrm{Cu}$ loading ratio $(0.10 \%)$, one in every four $\mathrm{Cu}$ atoms binds with $\mathrm{O}$ to form $\mathrm{Cu}_{1}{ }^{x+}$, which, in association with a neighboring $\mathrm{Cu}_{1}{ }^{0}$ atom, forms a stable $\mathrm{Cu}_{1}{ }^{0}-\mathrm{Cu}_{1}{ }^{x+}$ atom-pair structure. The current density and Faradaic efficiency of the reduction products are the indices to evaluate the performance for $\mathrm{CO}_{2} \mathrm{RR}$ (Fig. 5(b)). In the critical step of $\mathrm{CO}_{2}$ reduction, the $\mathrm{H}_{2} \mathrm{O}$ molecule adsorbed on $\mathrm{Cu}_{1}{ }^{x+}$ stabilizes the $\mathrm{CO}_{2}$ molecule chemisorbed on the neighboring $\mathrm{Cu}_{1}{ }^{0}$, and thereby promotes $\mathrm{CO}_{2}$ activation. This leads to a $\mathrm{FE}_{\mathrm{Co}}$ of over $92 \%$ (Fig. 5(c)), and the competing HER is almost completely suppressed. The sample at $-0.78 \mathrm{~V}$ for $180 \mathrm{~min}$ (Fig. 5 (d)) was subjected to stability assessment. The current density remained virtually unchanged, and the FE $\mathrm{Fo}$ showed only a small decline from the initial $92 \%$ to the final $80 \%$, indicating a relatively high CO selectivity. Experimental characterization and DFT revealed that the adsorption configuration reduces the activation energy, which generates high selectivity, activity, and stability under relatively low potentials. It is also notable that the atom pair is stabilized by surface defects of the nanostructures, which offers a novel and efficient method to construct functional interfaces at the atomic level. We believe that this method can also be applied to other catalytic systems, and opens up new opportunities for atomically dispersed catalysts to be used in more complex reactions.

\subsection{Others}

\subsubsection{Hydrogen evolution reaction}

Hydrogen energy is a very important part of the exploration of many new energy sources. Since the 1970s, hydrogen mole- cules have been considered to be good energy carriers [115]. The storage of energy in the form of hydrogen fuel, which is used for combustion or converted into other forms of energy, has become a major part of the planned energy structure for the future. Hydrogen is considered a very good energy source because it has the highest energy density per unit mass, and in the process of combusting and releasing energy, it produces only water, a non-polluting product [116]. Compared with all types of fossil energy, hydrogen energy is a highly efficient, renewable, and non-polluting energy source. Therefore, research on hydrogen production and storage has been ongoing. Hydrogen evolution reaction (HER) can make full use of secondary energy to achieve the high-purity preparation of $\mathrm{H}_{2}$, and the selection of the catalyst is the key in this process. Currently, Pt and Pt-based materials are recognized as the most effective HER catalysts, but the high cost and scarce resources limit their large-scale application [117-120]. In order to better promote the development of hydrogen economy, it is imperative to design non-precious-metal catalysts with high catalytic performance and low cost to replace Pt. As an extension to the SAC family, DACs have attracted considerable research focus owing to their specific advantages.

Recently, Zhen et al. [74] prepared a nitrogen-doped mesoporous carbon structure material (CuCo@NC) embedded with $\mathrm{Cu}$ and $\mathrm{Co}$ dual metals by using the constrained copper thermal conversion method by pre-growing zeolite imidazole framework (ZIF-67) on $\mathrm{Cu}(\mathrm{OH})_{2}$ nanoparticles (Fig. 6(a)). The formation of the $\mathrm{Cu}-\mathrm{N}$ bond further increases the nitrogen content in the carbon skeleton material from ZIF-67 under high pyrolysis temperature conditions. Through this method, the materials obtained by researchers have the advantages of rich reactive active sites, high nitrogen doping, strong synergistic coupling and better mass activity, and have exhibited excellent performance in HER. The CuCo@NC composite exhibited excellent HER catalytic activity with a low onset overpotential of 


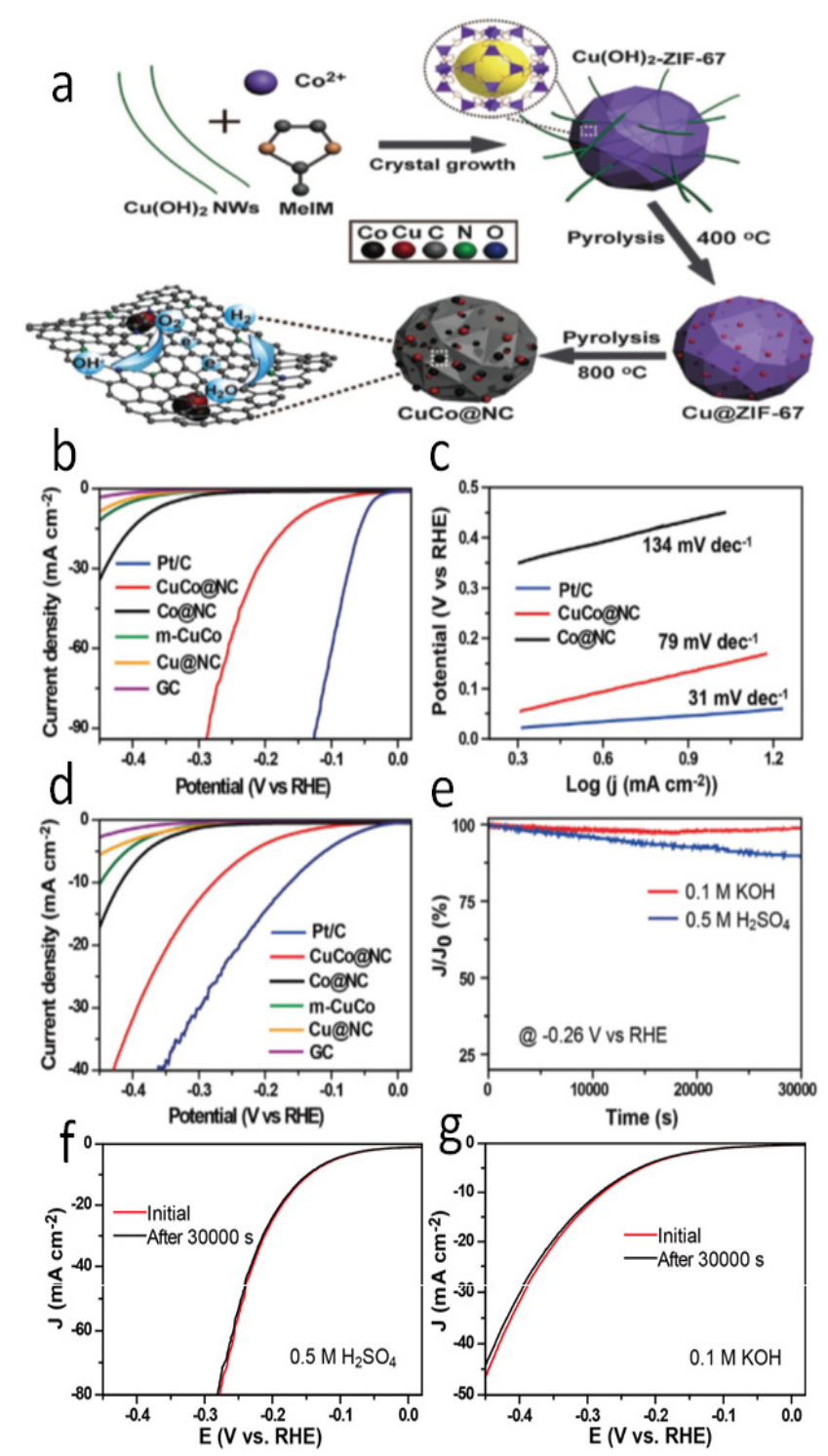

Fig. 6. (a) Schematic representation of the synthesis process of CuCo@NC electrocatalysts. MeIM: 2-methylimidazole. (b) LSV curves of various samples for hydrogen evolution in $0.5 \mathrm{M} \mathrm{H}_{2} \mathrm{SO}_{4}$, and (c) the corresponding Tafel curves. (d) LSV curves of various samples for hydrogen evolution in $0.1 \mathrm{M} \mathrm{KOH}$. (e) HER stability tests of CuCo@NC in $0.5 \mathrm{M} \mathrm{H}_{2} \mathrm{SO}_{4}$ and $0.1 \mathrm{M} \mathrm{KOH}$, respectively. LSV curves of CuCo@NC before and after stability test at an RDE rotation rate of $1600 \mathrm{rpm}$ in $0.5 \mathrm{M}$ $\mathrm{H}_{2} \mathrm{SO}_{4}$ (f) and $0.1 \mathrm{M} \mathrm{KOH} \mathrm{(g),} \mathrm{respectively.} \mathrm{Reproduced} \mathrm{with} \mathrm{permission}$ [74].

$115 \mathrm{mV}$, which is much smaller than that of Co@NC (320 mV), m-CuCo (360 mV), and Cu@NC (380 mV) (Fig. 6(b)). The Tafel slopes of the CuCo@NC and Co@NC catalysts were calculated as 79 and $134 \mathrm{mV} \mathrm{dec}^{-1}$, respectively (Fig. 6(c)). The low overpotential and small Tafel slope of CuCo@NC are comparable to the best reported non-precious-metal HER electrocatalysts. The similar trend of enhanced HER electrocatalytic activity for CuCo@NC was also observed in an alkaline electrolyte (Fig. 6(d)). The current density retention of the CuCo@NC catalyst was about $92.79 \%$ and $98.31 \%$ in $0.5 \mathrm{M} \mathrm{H}_{2} \mathrm{SO}_{4}$ and $0.1 \mathrm{M} \mathrm{KOH}$ electrolytes, respectively (Fig. 6(e)), comparable to the values for commercial $\mathrm{Pt} / \mathrm{C}$, clearly demonstrating the excellent HER catalytic activities and durability of the CuCo@NC catalyst over a wide $\mathrm{pH}$ range. The LSV curves showed almost no change after continuous operation for 30,000 s (Figs. 6(f) and (g)). From the above reactions, the material shows broad application potential in the field of HER electrocatalysis.

\subsubsection{Nitrogen reduction reaction}

Nitrogen reduction reaction (NRR) utilizes nitrogen and water to synthesize ammonia, which can directly convert electric energy generated by renewable energy into ammonia for easy storage and transportation, and ensure zero emission of carbon dioxide, providing a new idea for solving the current severe energy and environmental problems [121-123]. Ammonia is one of the significant inorganic chemical products and occupies an important position in the national economy. It is mainly used in synthetic fertilizers and chemical or medical raw materials. In recent years, ammonia is also been considered as a potential hydrogen storage material [124-126]. Therefore, for the sustainable development of society and economy, it is very crucial to transform the abundant nitrogen in the atmosphere into ammonia with high usable value. Nitrogen activation is difficult due to the strong bond energy ( $945 \mathrm{~kJ}$ $\left.\mathrm{mol}^{-1}\right)$ in the nitrogen-nitrogen triple bond $(\mathrm{N} \equiv \mathrm{N})$ in nitrogen gas. The traditional industrial nitrogen fixation method is expensive. Therefore, the main challenge in the ammonia synthesis process is the design of an efficient and low-cost catalyst for use in the nitrogen activation process that helps to achieve normal temperature and pressure synthesis [127]. As an extension of the SAC family, DACs have attracted considerable research interest owing to their specific advantages.

Chen et al. [57] demonstrated the outstanding advantages of DACs in NRR owing to the unique geometric and electronic properties. The authors constructed a catalytic system with high loading, high dispersion, and high stability; $\mathrm{C}_{2} \mathrm{~N}$ with uniform pore distribution was selected as the supporting substrate material of SACs and DACs. The $\mathrm{N}$ atom located in the pore of $\mathrm{C}_{2} \mathrm{~N}$ has a lone pair of electrons, which can anchor the transitional non-precious-metal atoms $(\mathrm{Cr}, \mathrm{Mn}, \mathrm{Fe}, \mathrm{Co}, \mathrm{Ni})$ in the pore of $\mathrm{C}_{2} \mathrm{~N}$, preventing them from diffusing in thermodynamics and dynamics, avoiding the agglomeration of metal atoms (abbreviated as $\mathrm{TM}-\mathrm{C}_{2} \mathrm{~N}, \mathrm{TM}_{2}-\mathrm{C}_{2} \mathrm{~N}$ ), and exhibiting excellent stability. The results showed that the catalytic activity of $\mathrm{TM}_{2}-\mathrm{C}_{2} \mathrm{~N}$ was

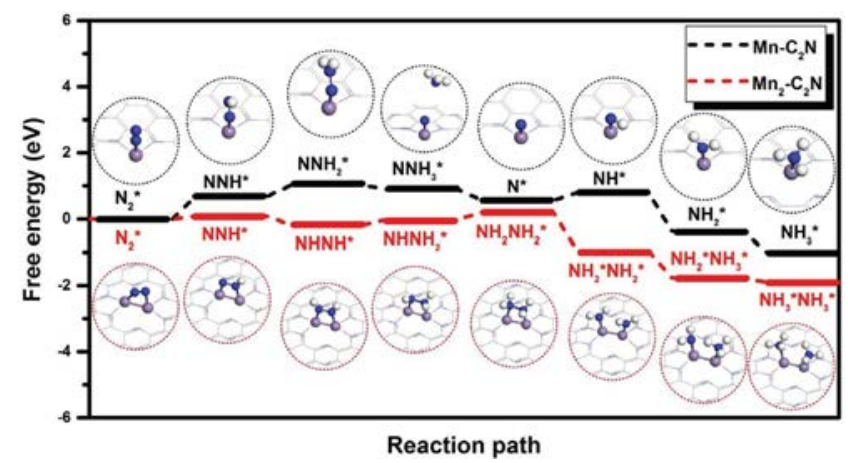

Fig. 7. Free energy diagram of $\mathrm{NRR}$ on $\mathrm{Mn}-\mathrm{C}_{2} \mathrm{~N}$ and $\mathrm{Mn}_{2}-\mathrm{C}_{2} \mathrm{~N}$ at an applied potential of $0 \mathrm{~V}$, including the corresponding geometric structures of intermediates. Reproduced with permission [57]. 
Table 3

Average bond length of TM-N and electron transfer from TM to $\mathrm{C}_{2} \mathrm{~N}$ in the $\mathrm{TMn}-\mathrm{C}_{2} \mathrm{~N}$ systems. Binding energy of $\mathrm{TM}$ on $\mathrm{TM}-\mathrm{C}_{2} \mathrm{~N}(\mathrm{TM}=\mathrm{Cr}, \mathrm{Mn}$, $\mathrm{Fe}, \mathrm{Co}, \mathrm{Ni}$ ).

\begin{tabular}{lcccc}
\hline & & $\begin{array}{c}\text { Average bond length } \\
\text { of TM-N }(\AA)\end{array}$ & $\begin{array}{c}\text { Electron } \\
\text { transfer(e) }\end{array}$ & $\begin{array}{c}\text { Binding energy of } \\
\text { TM on TM- } \mathrm{C}_{2} \mathrm{~N}(\mathrm{eV})\end{array}$ \\
\hline $\mathrm{Cr}$ & SAC & 2.11 & 0.525 & 2.72 \\
& $\mathrm{DAC}$ & 2.17 & 0.504. & \\
$\mathrm{Mn}$ & $\mathrm{SAC}$ & 2.22 & 0.534 & 2.25 \\
& $\mathrm{DAC}$ & 2.02 & 0.250 & \\
$\mathrm{Fe}$ & $\mathrm{SAC}$ & 1.88 & 0.265 & 4.34 \\
& $\mathrm{DAC}$ & 1.96 & 0.186 & \\
$\mathrm{Co}$ & $\mathrm{SAC}$ & 1.89 & 0.224 & 5.21 \\
& $\mathrm{DAC}$ & 2.04 & 0.102 & \\
$\mathrm{Ni}$ & $\mathrm{SAC}$ & 1.96 & 0.238 & 5.56 \\
& $\mathrm{DAC}$ & 2.00 & 0.116 & \\
\hline
\end{tabular}

significantly higher than that of $\mathrm{TM}-\mathrm{C}_{2} \mathrm{~N}$ for NRR owing to the stronger activation of nitrogen by the DACs (the adsorption of the DACs to intermediate state $\mathrm{NNH}^{*}$ is stronger and favors the first hydrogenation of nitrogen) (Fig. 7). The NRR catalytic activity of Mn was the best ( $-0.23 \mathrm{~V}$ vs. RHE) (Table 3$)$, which was better than the reported value. It is pointed out that DACs can replace SACs and become the best choice for NRR, providing a new idea for catalyst design of NRR.

\subsubsection{CO oxidation reaction}

The CO oxidation with low ambient temperature has significant industrial application value, and is widely used in many practical processes, such as air purification and automobile exhaust pollution $[128,129]$. The combination of the supporting substrate materials and metal clusters can promote the activation of $\mathrm{O}_{2}$ and the oxidation of CO. Typically supported metal clusters, especially those composed of precious metals, such as $\mathrm{Pt}, \mathrm{Pd}, \mathrm{Au}, \mathrm{Rh}$, and $\mathrm{Ru}$, have high activity for the oxidation of $\mathrm{CO}$. However, the conversion rate of $\mathrm{CO}$ oxidation catalyzed by noble metal nanoparticles is not high enough, and it is difficult to synthesize nanoparticles of uniform size and morphology experimentally, while the precious metal itself is expensive and its reserves on earth are limited. Therefore, it is crucial to develop low-temperature $\mathrm{CO}$ oxidation catalyst with low cost and high efficiency. As the catalytic activity of loading metal nanoparticles is related to their size and shape, DACs are preferred by researchers owing to their specific advantages for $\mathrm{CO}$ oxidation [130-134].

The catalytic properties of the heteronuclear DAC $\mathrm{Fe}_{1} \mathrm{Cu}_{1} @ \mathrm{C}_{2} \mathrm{~N}$ and its homonuclear DACs $\mathrm{Fe}_{2} @ \mathrm{C}_{2} \mathrm{~N}$ and $\mathrm{Cu}_{2} @ \mathrm{C}_{2} \mathrm{~N}$ for CO oxidation were systematically compared by Chen et al. [69]. Compared with homonuclear diatomic system $\mathrm{Fe}_{2} @ \mathrm{C}_{2} \mathrm{~N}$ and $\mathrm{Cu}_{2} @ \mathrm{C}_{2} \mathrm{~N}$, the heteronuclear diatomic system $\mathrm{Fe}_{1} \mathrm{Cu}_{1} @ \mathrm{C}_{2} \mathrm{~N}$ has superior catalytic performance for $\mathrm{CO}$ oxidation reaction: $\mathrm{Fe}_{2} @ \mathrm{C}_{2} \mathrm{~N}$ has strong adsorption for $\mathrm{O}_{2}$ and $\mathrm{O}$, which is not conducive to the formation of $\mathrm{CO}_{2}$. Although $\mathrm{Cu}_{2} @ \mathrm{C}_{2} \mathrm{~N}$ has a very low reaction energy barrier, the adsorption strength of $\mathrm{CO}$ is much higher than that of $\mathrm{O}_{2}$, indicating that homonuclear DACs are prone to $\mathrm{CO}$ poisoning and thus lose their catalytic activity. Compared with $\mathrm{Cu}_{2} @ \mathrm{C}_{2} \mathrm{~N}$, the adsorption energy of $\mathrm{O}_{2}$ on $\mathrm{Fe}_{1} \mathrm{Cu}_{1} @ \mathrm{C}_{2} \mathrm{~N}$ is slightly higher than that of $\mathrm{CO}$, and $\mathrm{O}_{2}$ can react with it to form $\mathrm{CO}_{2}$ in the case of $\mathrm{CO}$ adsorption and excess ad-

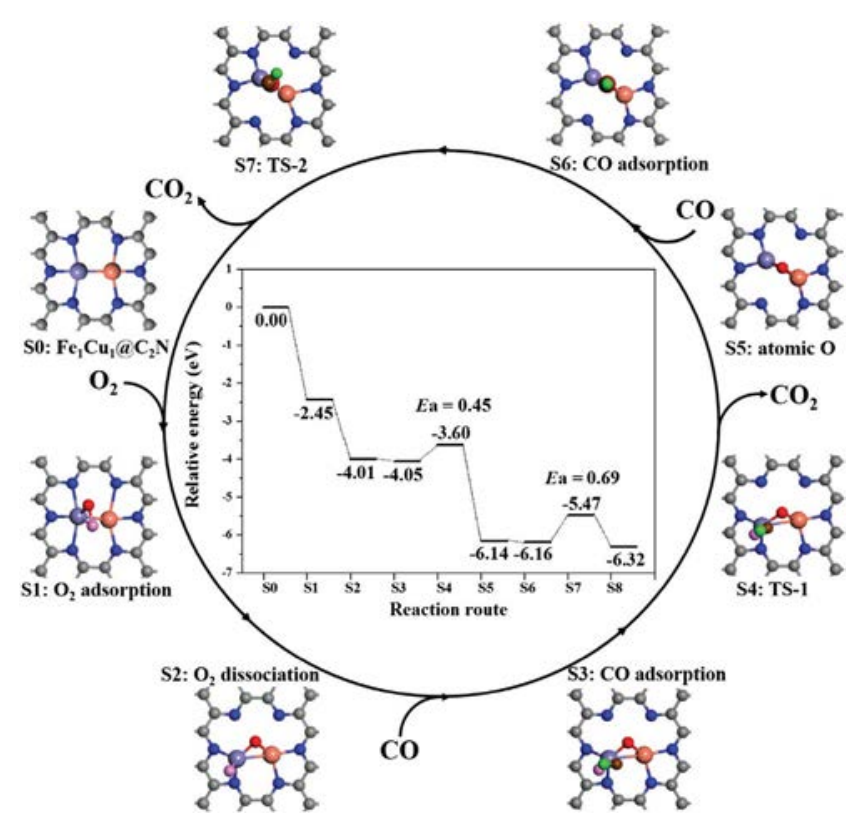

Fig. 8. The reaction pathways and energy profile for $\mathrm{CO}$ oxidation on the heteronuclear $\mathrm{Fe}_{1} \mathrm{Cu}_{1} @ \mathrm{C}_{2} \mathrm{~N}$ monolayer. Color scheme: $\mathrm{N}$, blue; $\mathrm{Fe}$, purple; $\mathrm{Cu}$, orange; $\mathrm{C}$ in $\mathrm{C}_{2} \mathrm{~N}$, gray; $\mathrm{C}$ in $\mathrm{CO}$, brown; $\mathrm{O}$ in $\mathrm{CO}$, green; $\mathrm{O}$ in $\mathrm{O}_{2}$, pink (first removed by $\mathrm{CO}$ ) and red (second removed by $\mathrm{CO}$ ). $\mathrm{Re}$ produced with permission [69].

sorption (two CO adsorptions first) (Fig. 8). The catalytic activity of the heteronuclear diatomic system $\mathrm{Fe}_{1} \mathrm{Cu}_{1} @ \mathrm{C}_{2} \mathrm{~N}$ was improved because two different metal atoms could coordinate with each other to more effectively adjust the center position of the d-band, so that the interaction between reactants or intermediates and the catalytic activity sites could be optimized. This work extends the research of SACs to heteronuclear DACs and provides a new horizon for the development of new catalysts. Considering the diversity of heteronuclear bimetallic atomic combinations, we expect more heteronuclear bimetallic atomic systems to be developed.

\section{Dual-atom catalysts in practical electrochemical energy devices}

\subsection{Fuel cells}

Fuel cells have broad development prospects because of their numerous advantages [135-137]. However, Pt, a precious metal, is still the most widely used electrocatalytic catalyst for oxygen reduction in fuel cells, and its price, activity, and stability are the main factors limiting the large-scale commercial use of fuel cells. DACs have attracted considerable research interest owing to their higher loading and stronger interaction between the metal and the supporting substrates materials compared with SACs, which ensures the highly efficient implementation of the four-electron oxygen reduction reaction of the fuel cell in the ORR.

Zhao et al. [70] prepared a uniformly dispersed $\mathrm{Zn} / \mathrm{o}-\mathrm{NC}_{x}-\mathrm{C}$ diatomic high-efficiency oxygen reduction catalyst based on the competitive coordination strategy. Owing to the active site of $\mathrm{Zn}$-Co diatomic pair with high activity, the catalyst showed 

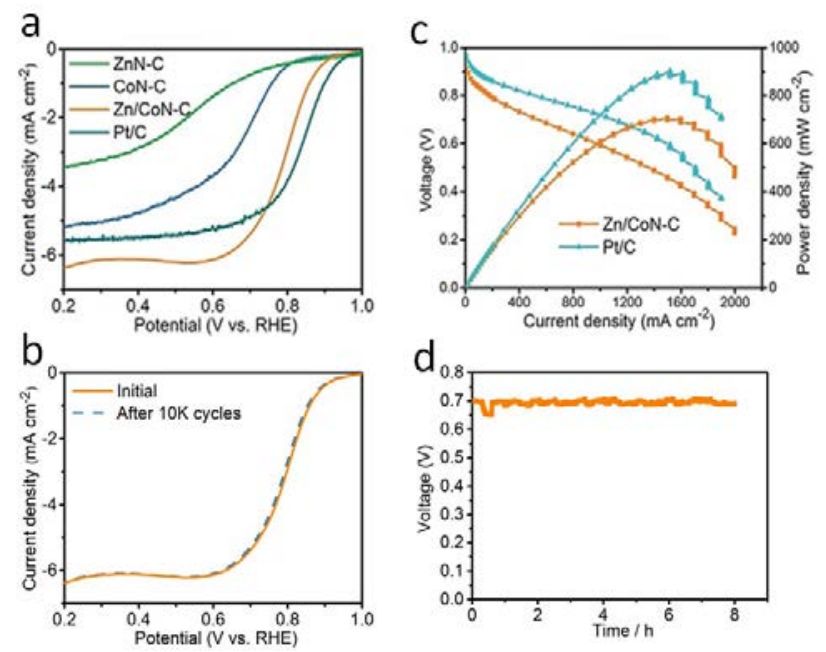

Fig. 9. (a) ORR Linear scan voltammogram (LSV) curves for different catalysts in $0.1 \mathrm{M} \mathrm{HClO}_{4}$ solution. (b) LSV polarization curves of $\mathrm{Zn} / \mathrm{Co}-\mathrm{N}-\mathrm{C}$ before and after $10 \mathrm{~K}$ potential cycles in $\mathrm{O}_{2}$-saturated $0.1 \mathrm{M}$ $\mathrm{HClO}_{4}$. (c) $\mathrm{H}_{2} / \mathrm{O}_{2}$ fuel cell polarization plots. (d) Stability of $\mathrm{Zn} / \mathrm{Co}-\mathrm{N}-\mathrm{C}$ in a $\mathrm{H}_{2} / \mathrm{O}_{2}$ fuel cell measured at $500 \mathrm{~mA} \mathrm{~cm}{ }^{-2}$. Reproduced with permission [70].

remarkable catalytic activity and stability under both alkaline $\left(E_{\text {onset }}=1.004 \mathrm{~V}, E_{1 / 2}=0.861 \mathrm{~V}\right)$ and acidic conditions $\left(E_{\text {onset }}=\right.$ $0.97 \mathrm{~V}, E_{1 / 2}=0.796 \mathrm{~V}$ ) (Figs. 9(a) and (b)). The catalyst was applied to a power density of $705 \mathrm{~mW} \mathrm{~cm}^{-2}$ (about $78 \%$ of commercial Pt/C) in $\mathrm{H}_{2} / \mathrm{O}_{2}$ fuel cells (Fig. 9(c)) and exhibited no degradation of activity after $8 \mathrm{~h}$ of stability testing (Fig. 9(d)). The above results indicate that the catalyst has great practical application potential in fuel cells.

Wu et al. [71] successfully synthesized an electrocatalyst in which diatomic $\mathrm{Fe}-\mathrm{Co}$ was co-anchored on porous nitrogen-doped carbon (Fig. 3(a)). Diatomic materials have demonstrated high ORR performance for both $\mathrm{H}_{2} /$ air and $\mathrm{H}_{2} / \mathrm{O}_{2}$ fuel cells. In acidic ORR, the $E_{1 / 2}$ was $0.863 \mathrm{~V}, E_{\text {onset }}$ was $1.06 \mathrm{~V}$ (Fig. 3(c)), the current density at $0.9 \mathrm{~V}$ was $2.842 \mathrm{~mA} \mathrm{~cm}^{-2}$, and the performance was excellent after 50,000 cycles (Fig. 3(e)). The highest output power of the $\mathrm{H}_{2} / \mathrm{O}_{2}$ fuel cell is up to $0.98 \mathrm{~W} \mathrm{~cm}^{-2}$ (Fig. 10(a)). In the $\mathrm{H}_{2}$ /air fuel cell, the maximum output power is $0.51 \mathrm{~W} \mathrm{~cm}^{-2}$ (Fig. 10(b)), and the stable operation is more than $100 \mathrm{~h}$ (Fig. 10 (c)). The $\mathrm{H}_{2}$ /air fuel cell of the diatomic materials has the highest performance among the non-Pt catalysts, and increases the existing maximum activity by $20 \%$. In this research, DACs have been successfully applied as the cathode catalyst of fuel cells, greatly reducing the cost of the catalytic layer, which is a major breakthrough in the field of fuel cells. This increases the potential for commercial development of fuel cells, and is expected to facilitate the development of fuel cell vehicle in the future.

\subsection{Metal-air battery}

For commercial applications of zinc batteries, low cost and high performance ORR catalysts are urgently needed. It is highly desirable to explore non-precious-metal catalysts that exhibit ORR performance comparable to that of noble metal catalysts. Heteronuclear DACs formed by the combination of transition metals has shown promising prospects as a cathode catalyst for $\mathrm{Zn}$-air batteries, demonstrating its high potential in practical applications [138-141].

Zhao et al. [70] prepared a uniformly dispersed $\mathrm{Zn} / \mathrm{Co}-\mathrm{N}_{x}-\mathrm{C}$ diatomic highly efficient oxygen reduction catalyst based on competitive coordination strategy. Owing to the active site of $\mathrm{Zn}$-Co diatomic pair with high activity, the catalyst applied to Zn-air battery exhibits a maximum power density of $230 \mathrm{~mW}$ $\mathrm{cm}^{-2}$ outperforming the $\mathrm{Pt} / \mathrm{C}$-based counterpart $(201 \mathrm{~mW}$ $\mathrm{cm}^{-2}$ ) (Fig. 11(a)). Furthermore, no significant potential change was detected at a current density of $5 \mathrm{~mA} \mathrm{~cm}^{-2}$ for $100,000 \mathrm{~s}$ (Fig. 11(b)), indicating stable practical application performance. As shown in Fig. 4(b) inset, two series-connected Zn-air batteries based on the $\mathrm{Zn} / \mathrm{Co}-\mathrm{N}-\mathrm{C}$ as the cathode can power a series of red light-emitting diodes (LEDs) in parallel (2.2 V) with outstanding stability. These results not only indicate that the catalyst has great application potential in the metal-air batteries, but also provide a reference for the preparation of highly active DACs in large quantities. The detailed characterization and theoretical calculations provide a deeper understanding of the origin of the activity of the DACs, and are important for guiding the synthesis and mechanism of other electrocatalytic catalysts.

$\mathrm{Wu}$ et al. [75] constructed a novel electrocatalyst by precisely controlling the bonding between the Fe species and the Co node in the original bimetallic MOF, in which Fe-Co double sites are embedded in $\mathrm{N}$-doped carbon nanotubes $((\mathrm{Fe}$, Co)/CNT) (Fig. 12(a)). The resulting catalyst exhibited the most
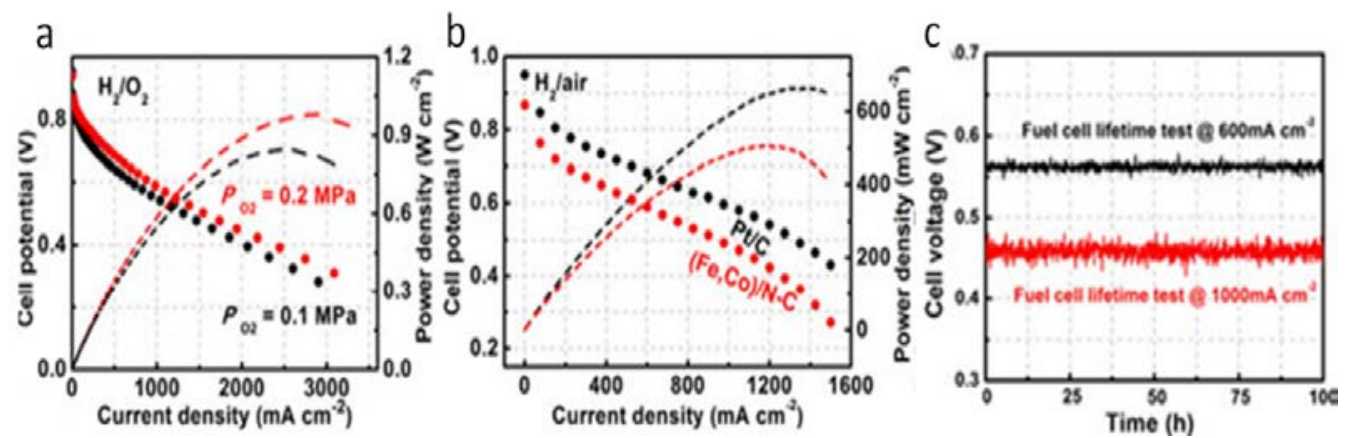

Fig. 10. (a) $\mathrm{H}_{2} / \mathrm{O}_{2}$ fuel cell polarization plots. (b) $\mathrm{H}_{2} /$ air fuel cell polarization plots. (c) Stability of $(\mathrm{Fe}, \mathrm{Co}) / \mathrm{N}-\mathrm{C}$ in a $\mathrm{H}_{2} /$ air fuel cell measured at 600 $\mathrm{mA} \mathrm{cm}-2$ and $1000 \mathrm{~mA} \mathrm{~cm}^{-2}$. Reproduced with permission [71]. 


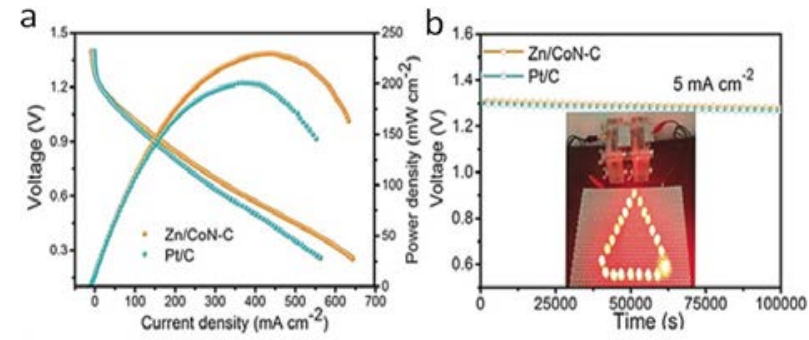

Fig. 11. (a) Polarization and power density curves of primary $\mathrm{Zn}$-air batteries using $\mathrm{Zn} / \mathrm{Co}-\mathrm{N}-\mathrm{C}$ and $\mathrm{Pt} / \mathrm{C}$ as ORR catalyst in $6 \mathrm{M} \mathrm{KOH}$ electrolyte. (b) Galvanostatic discharge of the fabricated $\mathrm{Zn}$-air batteries and the inset is the photograph of LEDs powered by two liquid $\mathrm{Zn}$-air batteries in series. Reproduced with permission [70].

advanced ORR activity and excellent Zn-air battery performance. It has an admirable initial potential ( $E_{\text {onset, }} 1.15 \mathrm{~V}$ vs. $1.05 \mathrm{~V})$ and a half-wave potential $\left(E_{1 / 2}, 0.954 \mathrm{~V}\right.$ and $\left.0.842 \mathrm{~V}\right)$, which is superior to commercial Pt/C (Fig. 12(b)). ORR tests showed that (Fe, Co)/CNT has better performance than most reported non-precious-metal catalysts in alkaline electrolytes. Further, when used as a cathode catalyst in the Zn-air battery, (Fe, Co)/CNT exhibited high voltages of 1.31 and $1.23 \mathrm{~V}$ at discharge current densities of 20 and $50 \mathrm{~mA} \mathrm{~cm}^{-2}$, respectively (Figs. 12(c) and (e)). In addition, the power density and specific energy density reached 260 and $870 \mathrm{Wh} \mathrm{kgzn}^{-1}$ (Figs. 12(d) and (e)). Experimental and DFT results show that the synergy between the Fe-Co dual metals effectively weakens the $0-0$ bond

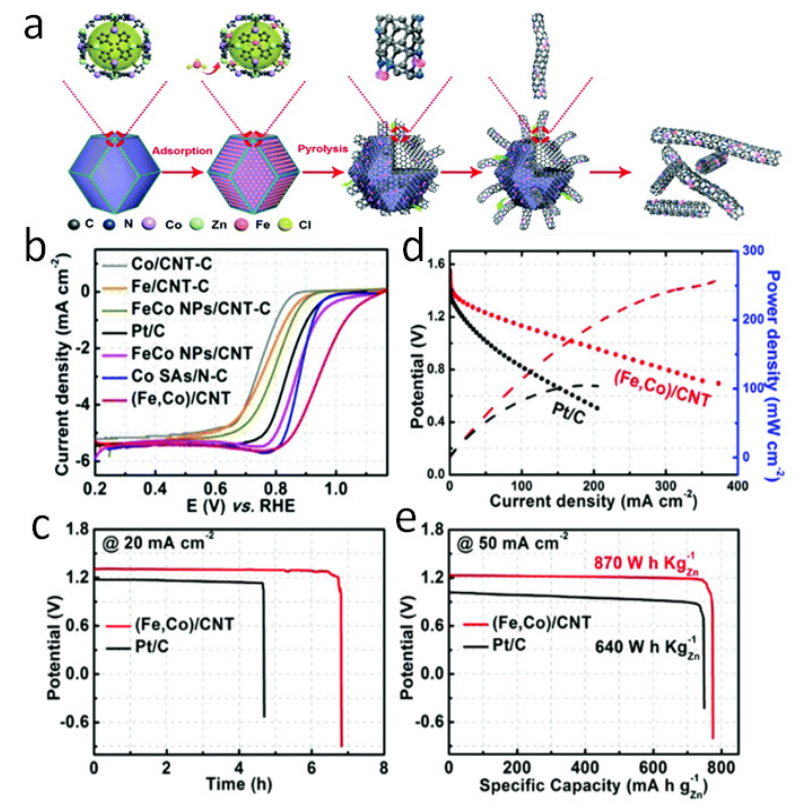

Fig. 12. (a) Schematic illustration of the preparation of the (Fe, Co)/CNT. (b) RDE polarization curves of samples in $\mathrm{O}_{2}$-saturated $0.1 \mathrm{M}$ $\mathrm{KOH}$. (c) Galvanostatic discharge curves of Zn-air batteries employing (Fe, Co)/CNT and Pt/C as the cathode catalyst at $20 \mathrm{~mA} \mathrm{~cm}^{-2}$. (d) Discharge polarization curves and the corresponding power density of $\mathrm{Zn}$-air batteries with the (Fe, Co)/CNT and Pt/C as cathode catalysts. (e Long-term galvanostatic discharge curves of $\mathrm{Zn}$-air batteries before complete consumption of the $\mathrm{Zn}$ anode at $50 \mathrm{~mA} \mathrm{~cm}^{-2}$. Reproduced with permission [75]. in favor of oxygen activation. These results not only help to deepen the understanding of the relationship between the structure and properties of non-precious-metal electrocatalysts and the identified active sites, but also provide new possibilities for the advancement of catalyst design in the field of metal-air batteries.

\section{Summary and perspective}

Advanced nanocatalysis technology brings new opportunities in the fields of energy, environmental protection, and chemical synthesis, and is an important way to realize the transformation of society from fossil energy to emerging energy systems. In recent years, the sudden emergence of SACs has injected new vitality into this field [142]. When the dispersion of metal particles reaches the size of a single atom, it will result in novel characteristics such as the quantum size effect, unsaturated coordination environment, and interaction of metals and the supporting substrates materials. Compared with traditional catalysts, SACs have obvious advantages, such as fully exposed active sites, high selectivity, and maximized atom utilization. However, single atoms have a significantly increased surface free energy, which can lead to the aggregation of particles and the reduction of catalytic activity sites during the preparation and catalysis. In order to avoid the formation of metal nanocrystals due to the large surface energy of individual metal atoms, the currently reported loading of synthetic catalysts is relatively low, generally less than $1.5 \%$, resulting in low overall activity. These problems seriously restrict the development and application of SACs.

Considering the small contact area between the single atom and the supporting substrate materials and the relatively weak interaction, DACs have recently emerged in order to further increase the number and loading of monatomic active sites. DACs have been successfully applied in various catalytic systems, fuel cells, and metal-air battery, and have exhibited remarkable performance. Compared with SACs, DACs have many distinct advantages, such as higher metal atomic loading and more flexible active sites. In addition, the two metal atoms can cooperate with each other to more effectively adjust the center position of the d-band, so that the interaction between reactants or intermediates and catalytic active sites can be optimized. This advantage is particularly prominent in heteronuclear DACs. In this review, we summarize the work of currently reported DACs, especially in terms of the advantages, synthesis, and characterization of DACs, and we describe the applications of DACs in electrochemical energy conversion and storage devices. In particular, we classify the current work related to DACs into homonuclear DACs and heteronuclear DACs, and we fully summarize the catalytic systems currently used in both types of DACs. It can be seen that, compared with precious metal DACs, the work on non-precious-metal DACs is more general. Considering the high cost and shortage of resource reserves of precious metals, DACs containing "precious metals atom-non-precious-metal atom" and "non-precious-metal atom-non-precious-metal atom" have great prospects for future research. In principle, two different metal atoms will form a 


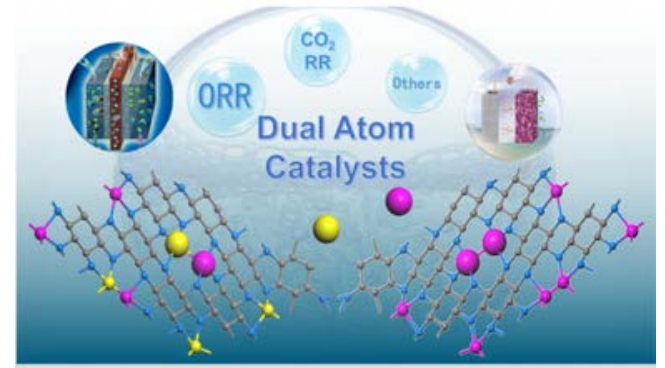

Fig. 13. Current status of the development of DACs, for homonuclear and heteronuclear DACs, including their synthesis, characterization, the application of electrocatalytic systems, electrochemical energy devices, and other potential avenues.

variety of heteronuclear DACs, so there are more possibilities for researching heteronuclear DACs with excellent performance.

Although DAC application and research has been rather successful, it is important to recognize that the preparation of highly dispersed DACs remains a key challenge because metal atoms inevitably aggregate during the synthesis process. In addition, the accurate identification of active sites in DACs remains a problem that requires additional research. Moreover, the properties of active sites are very significant in the performance of the catalysts. The identification of active sites will help us gain a deeper understanding of the reaction mechanism occurring on the catalyst surface, which in turn will provide strategies for further rational design of DACs. It can be seen that the current application of the DAC catalytic system is mainly focused on ORR and $\mathrm{CO}_{2} \mathrm{RR}$, and there is relatively little work on other catalytic systems. Although this is a drawback, it provides direction for future research on DACs (Fig. 13).

It can be foreseen that the development of DACs will cover for the drawbacks of SACs and offer an overall advantage in electrochemical energy conversion and storage. With the help of the diversity of two different metal atoms in heteronuclear DACs, research on transition-metal-based DACs will contribute significantly to the conservation of precious metal resources and the environment. Further design and optimization of DACs will also provide greater economic and social benefits for fuel cells and metal-air batteries. Therefore, we believe that the combination of DACs with electrochemical energy conversion and storage will be a new frontier in materials research and open up new research paths for the synthesis of more efficient electrocatalysts.

\section{References}

[1] M. Winter, R. J. Brodd, Chem. Rev., 2004, 104, 4245-4270.

[2] L. Tao, Y. Zhao, Y. F. Zhao, S. Huang, Y. Yang, Q. Tong, F. Gao, J. Phys. Chem. Solids, 2018, 113, 61-66.

[3] J. Zhang, C. Zhang, Y. F. Zhao, I. S. Amiinua, H. Zhou, X. Liu, Y. Tang, S. C. Mu, Appl. Catal. B: Environ., 2017, 211, 148-156.

[4] I. C. Man, H. Y. Su, F. Calle-Vallejo, H. A. Hansen, J. I. Martínez, N. G. Inoglu, J. Kitchin, T. F. Jaramillo, J. K. Nörskov, J. Rossmeisl, ChemCatChem, 2011, 3, 1159-1165.

[5] Y. Gorlin, T. F. Jaramillo, J. Am. Chem. Soc., 2010, 132, 13612-13614.

[6] Y. J. Wang, B. Z. Fang, D. Zhang, A. J. Li, D. P. Wilkinson, A. Ignaszak, L. Zhang, J. J. Zhang, Electrochem. Energy Rev., 2018, 1, 1-34.

[7] M. K. Debe, Nature, 2012, 486, 43-51.

[8] N. Tian, B. A. Lu, X. D. Yang, R. Huang, Y. X. Jiang, Z. Y. Zhou, S. G. Sun, Electrochem. Energy Rev., 2018, 1, 54-83.

[9] A. P. Yu, Z. W. Chen, R. Maric, L. Zhang, J. J. Zhang, J. Y. Yan, Appl. Energy, 2015, 153, 1-2.

[10] C. Z. Zhu, Q. R. Shi, S. Feng, D. Du, Y. H. Lin, Appl. Energy, 2018, 3, 1713-1721.

[11] M. A. Khan, H. B. Zhao, W. W. Zou, W. Zou, Z. Chen, W. J. Cao, J. H. Fang, J. Q. Xu, L. Zhang, J. J. Zhang, Electrochem. Energy Rev., 2018, 1, 483-530.

[12] Y. P. Zhao, L. Tao, W. Dang, L. L. Wang, M. R. Xia, B. Wang, M. M. Liu, F. M. Gao, J. J. Zhang, Y. F. Zhao, Small, 2019, 15, 1900288.

[13] J. Y. Liu, ACS Catal., 2016, 7, 34-59.

[14] J. Lin, A. Q. Wang, B. T. Qiao, X. Y. Liu, X. F. Yang, X. D. Wang, J. X. Liang, J. Li, J. Y. Liu, T. Zhang, J. Am. Chem. Soc., 2013, 135, 15314-15317.

[15] X. F. Yang, A. Q. Wang, B. T. Qiao, J. Li, J. Y. Liu, T. Zhang, Acc. Chem. Res., 2013, 46, 1740-1748.

[16] Y. Lei, F. Mehmood, S. Lee, J. Greeley, B. Lee, S. Seifert, R. E. Winans, J. W. Elam, R. J. Meyer, P. C. Redfern, D. Teschner, R. Schlögl, M. J.

\section{Graphical Abstract}

Chin. J. Catal., 2020, 41: 783-798 doi: 10.1016/S1872-2067(20)63536-7

\section{Supported dual-atom catalysts: Preparation, characterization, and potential applications}

Jing Zhang, Qiuan Huang, Juan Wang *, Jing Wang, Jiujun Zhang, Yufeng Zhao *

Shanghai University;

Xi'an University of Architecture and Technology;

Yanshan University

Dual-atom catalysts, for homonuclear and heteronuclear dual-atom catalysts, including their synthesis, characterization, and the application of electrocatalytic systems and electrochemical energy devices.

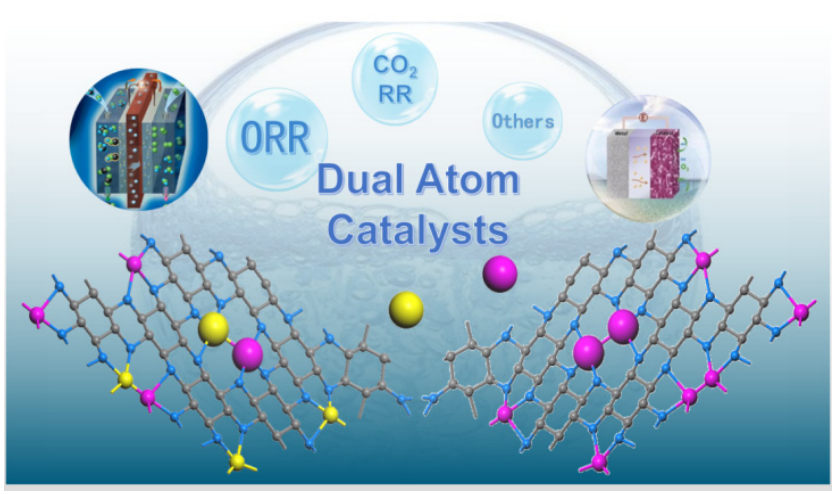


Pellin, L. A. Curtiss, S. Vajda, Science, 2010, 328, 224-228.

[17] J. H. Kim, D. J. Suh, T. J. Park, K. L. Kim, Appl. Catal. A, 2000, 197, 191-200.

[18] S. Vajda, M. G. White, ACS Catal., 2015, 5, 7152-7176.

[19] E. C. Tyo, S. Vajda, Nat. Nanotechnol., 2015, 10, 577-588.

[20] H. J. Yin, H. J. Tang, D. Wang, Y. Gao, Z. Y. Tang, ACS Nano, 2012, 6, 8288-8297.

[21] F. Yang, D. H. Deng, X. L. Pan, Q. Fu, X. H. Bao, Nat. Sci. Rev., 2015, 2, 183-201.

[22] W. Chen, S. W. Chen, Angew. Chem. Int. Ed., 2009, 48, 4386-4389.

[23] Y. F. Zhao, S. F. Huang, M. R. Xia, S. Rehman, S. C. Mu, Z. K. Kou, Z. Zhang, Z. Y. Chen, F. M. Gao, Y. L. Hou, Nano Energy, 2016, 28, 346-355.

[24] Z. Y. Lu, J. Wang, S. F. Huang, Y. L. Hou, Y. G. Li, Y. P. Zhao, S. C. Mu, J. J. Zhang, Y. F. Zhao, Nano Energy., 2017, 42, 334-340.

[25] W. Zhang, W. T. Zheng, Adv. Funct. Mater., 2016, 26, 2988-2993.

[26] S. X. Liang, C. Hao, Y. T. Shi, ChemCatChem, 2015, 7, 2559-2567.

[27] B. T. Qiao, A. Q. Wang, X. F. Yang, L. F. Allard, Z. Jiang, Y. T. Cui, J. Y. Liu, J. Li, T. Zhang, Nat. Chem., 2011, 3, 634-641.

[28] B. T. Qiao, J. X. Liang, A. Q. Wang, J. Y. Liu, T. Zhang, Chin. J. Catal., 2016, 37, 1580-1586.

[29] H. S. Wei, X. Y. Liu, A. Q. Wang, L. L. Zhang, B. T. Qiao, X. F. Yang, Y. Q. Huang, S. Miao, J. Y. Liu, T. Zhang, Nat. Commun., 2014, 5, 5634.

[30] J. X. Liang, X. F. Yang, A. Q. Wang, T. Zhang, J. Li, Catal. Sci. Technol., 2016, 6, 6886-6892.

[31] B. T. Qiao, J. X. Liang, A. Q. Wang, C. Q. Xu, J. Li, T. Zhang, J. Y. Liu, Nano Res., 2015, 8, 2913-2924.

[32] J. X. Liang, J. Lin, X. F. Yang, A. Q. Wang, B. T. Qiao, J. Y. Liu, T. Zhang, J. Li, A. J. Phys. Chem. C, 2014, 118, 21945-21951.

[33] J. Lin, B. T. Qiao, N. Li, L. Li, X. C. Sun, J. Y. Liu, X. D. Wang, T. Zhang, Chem. Commun., 2015, 51, 7911-7914.

[34] A. J. Therrien, A. J. R. Hensley, M. D. Marcinkowski, R. Q. Zhang, F. R. Lucci, B. Coughlin, A. C. Schilling, J. S. McEwen, E. C. H. Sykes, Nat. Catal., 2018, 1, 192-198.

[35] M. Moses-Debusk, M. Yoon, L. F. Allard, D. R. Mullins, Z. L. Wu, X. F. Yang, G. Veith, G. M. Stocks, C. K. Narula, J. Am. Chem. Soc., 2013, 135, 12634-12645.

[36] L. Wang, S. R. Zhang, Y. Zhu, A. Patlolla, J. J. Shan, H. Yoshida, S. Takeda, A. I. Frenkel, F. Tao, ACS Catal., 2016, 3, 1011-1019.

[37] B. T. Qiao, J. Lin, A. Q. Wang, Y. Chen, T. Zhang, J. Y. Liu, Chin. J. Catal., 2015, 36, 1505-1511.

[38] B. T. Qiao, J. X. Liu, Y. G. Wang, Q. Q. Lin, X. Y. Liu, A. Q. Wang, J. Li, T. Zhang, J. Y. Liu, ACS Catal., 2017, 5, 6249-6254.

[39] Z. W. Huang, X. Gu, Q. Q. Cao, P. P. Hu, J. M. Hao, J. H. Li, X. F. Tang, Angew. Chem. Int. Ed., 2012, 51, 4198-4203.

[40] D. Yang, S. J. Zhang, P. H. Xu, N. D. Browning, D. A. Dixon, B. C. Gates, Chem. Eur. J., 2017, 23, 2532-2536.

[41] Y. J. Chen, S. F. Ji, C. Chen, Q. Peng, D. S. Wang, Y. D. Li, Joule, 2018, 2, 1242-1264.

[42] Z. J. Li, D. H. Wang, Y. E. Wu, Y. D. Li, Natl. Sci. Rev., 2018, 5, 673-689.

[43] L. Zhang, K. Doyle-Davis, X. L. Sun, Energy Environ. Sci., 2019, 12, 492-517.

[44] H. J. Li, Y. D. Li, M. T. M. Koper, F. Calle-Vallejo, J. Am. Chem. Soc., 2014, 136, 15694-15701.

[45] X. Hong, K. Chan, C. Tsai, J. K. Nörskov, ACS Catal., 2016, 6, 4428-4437.

[46] F. Calle-Vallejo, D. Loffreda, M. T. M. Koper, P. Sautet, Nat. Chem., 2015, 7, 403-410.

[47] S. Martin, P. L. Garcia-Ybarra, J. L. Castillo, J. Power Sources, 2010, 195, 2443-2449.
[48] Z. Y. Wu, X. X. Xu, B. C. Hu, H. W. Liang, Y. Lin, L. F. Chen, S. H. Yu, Angew. Chem. Int. Ed., 2015, 54, 8179-8183.

[49] P. X. Liu, Y. Zhao, R. X. Qin, S. G. Mo, G. X. Chen, L. Gu, D. M. Chevrier, P. Zhang, Q. Guo, D. D. Zang, B. H. Wu, G. Fu, N. F. Zheng, Science, 2016, 352, 797-800.

[50] P. Song, M. Luo, X. Z. Liu, W. Xing, W. L. Xu, Z. Jiang, L. Gu, Adv. Funct. Mater., 2017, 27, 1700802.

[51] J. Li, S. G. Chen, N. Yang, M. M. Deng, S. Ibraheem, J. H. Deng, J. Li, L. Li, Z. D. Wei, Angew. Chem. Int. Ed., 2019, 58, 7035-7039.

[52] C. H. Choi, M. Kim, H. C. Kwon, S. J. Cho, S. Yun, H. T. Kim, K. J. J. Mayrhofer, H. Kim, M. Choi, Nat. Commun., 2016, 7, 10922.

[53] X. Zhou, Q. Shen, K. D. Yuan, W. S. Yang, Q. W. Chen, Z. H. Geng, J. L. Zhang, X. Shao, W. Chen, G. Q. Xu, X. M. Yang, K. Wu, J. Am. Chem. Soc., 2018, 140, 554-557.

[54] Z. Chen, Q. Zhang, W. X. Chen, J. C. Dong, H. R. Yao, X. B. Zhang, X. J. Tong, D. S. Wang, Q. Peng, C. Chen, W. He, Y. D. Li, Adv. Mater., 2017, 30, 1704720.

[55] E. Ruckenstein, H. Y. Wang, J. Catal., 2002, 205, 289-293.

[56] H. L. Li, L. B. Wang, Y. Z. Dai, Z. T. Pu, Z. H. Lao, Y. W. Chen, M. L. Wang, X. S. Zheng, J. F. Zhu, W. H. Zhang, R. Si, C. Ma, J. Zeng, Nat. Nanotechnol., 2018, 13, 411-417.

[57] S. Kandula, K. R. Shrestha, N. H. Kim, J. H. Lee, Small, 2018, 14, 1800291.

[58] M. L. Xiao, H. Zhang, Y. T. Chen, J. B. Zhu, L. Q. Gao, Z. Jin, J. J. Ge, Z. Jiang, S. L. Chen, C. P. Liu, W. Xing, Nano Energy, 2018, 46, 396-403.

[59] H. Yan, Y. Lin, H. Wu, W. H. Zhang, Z. H. Sun, H. Cheng, W. Liu, C. L. Wang, J. J. Li, X. H. Huang, T. Yao, J. L. Yang, S. Q. Wei, J. L. Lu, Nat. Commun., 2017, 8, 1070.

[60] J. Zhao, J. X. Zhao, F. Y. Li, Z. F. Chen, J. Phys. Chem. C, 2018, 122, 19712-19721.

[61] S. B. Tian, Q. Fu, W. X. Chen, Q. C. Feng, Z. Chen, J. Zhang, W. C. Cheong, R. Yu, L. Gu, J. C. Dong, J. Luo, C. Chen, Q. Peng, C. Draxl, D. S. Wang, Y. D. Li, Nat. Commun., 2018, 9, 2353.

[62] Z. Y. He, K. He, A. W. Robertson, A. I. Kirkland, D. Kim, J. Ihm, E. Yoon, G. D. Lee, J. H. Warner, Nano Lett., 2014, 14, 3766-3772.

[63] Y. W. Li, H. B. Su, S. H. Chan, Q. Sun, ACS Catal., 2015, 5, 6658-6664.

[64] H. M. Shen, Y. W. Li, Q. Sun, J. Phys. Chem. C, 2017, 121, 3963-3969.

[65] J. Q. Jiao, R. Lin, S. J. Liu, W. C. Cheong, C. Zhang, Z. Chen, Y. Pan, J. G. Tang, K. L. Wu, S. F. Hung, H. M. Chen, L. R. Zheng, Q. Lu, X. Yang, B. J. Xu, H. Xiao, J. Li, D. S. Wang, Q. Peng, C. Chen, Y. D. Li, Nat. Chem., 2019, 11, 222-228.

[66] E. Yeager, J. Mol. Catal., 1986, 38, 5-25.

[67] J. P. Collman, P. Denisevich, Y. Konai, M. Marrocco, C. Koval, F. C. Anson, J. Am. Chem. Soc., 1980, 102, 6027-6036.

[68] N. R. Sahraie, U. I. Kramm, J. Steinberg, Y. J. Zhang, A. Thomas, T. Reier, J. P. Paraknowitsch, P. Strasser, Nat. Commun., 2015, 6, 8618-8627.

[69] Y. Zhang, S. Yang, S. Wang, H. K. Liu, S. X. Dou, X. Liu, Small, 2019, $14,1800480$.

[70] Z. Y. Lu, B. Wang, Y. F. Hu, W. Liu, Y. F. Zhao, R. O. Yang, Z. P. Li, J. Luo, B. Chi, Z. Jiang, M. S. Li, S. C. Mu, S. J. Liao, J. J. Zhang, X. L. Sun, Angew. Chem. Int. Ed., 2019, 58, 2622-2626.

[71] J. Wang, Z. Q. Huang, W. Liu, C. R. Chang, H. L. Tang, Z. J. Li, W. X. Chen, C. J. Jia, T. Yao, S. Q. Wei, Y. E. Wu, Y. D. Li, J. Am. Chem. Soc., 2017, 139, 17281-17284.

[72] W. H. Ren, X. Tan, W. F. Yang, C. Jia, S. M. Xu, K. X. Wang, S. C. Smith, C. Zhao, Angew. Chem. Int. Edit., 2019, 58, 6972-6976.

[73] Z. H. Li, H. Y. He, H. B. Cao, S. M. Sun, W. L. Diao, D. L. Gao, P. L. Lu, S. S. Zhang, Z. Guo, M. J. Li, R. J. Liu, D. H. Ren, C. M. Liu, Y. Zhang, Z. Yang, J. K. Jiang, G. J. Zhang, Appl. Catal. B, 2019, 240, 112-121. 
[74] M. Kuang, Q. H. Wang, P. Han, G. F. Zheng, Adv. Energy Mater., 2017, 7, 1700193.

[75] J. Wang, W. Liu, G. Luo, Z. J. Li, C. Zhao, H. R. Zhang, M. Z. Zhu, Q. Xu, X. Q. Wang, C. M. Zhao, Y. T. Qu, Z. K. Yang, T. Yao, Y. F. Li, Y. Lin, Y. E. Wu, Y. D. Li, Energy Environ. Sci., 2018, 11, 3375-3379.

[76] J. K. Nörskov, T. Bligaard, J. Rossmeisl, C. H. Christensen, Nat. Chem., 2009, 1, 37-46.

[77] A. Ruban, B. Hammer, P. Stoltze, H. L. Skriver, J. K. Nörskov, J. Mol. Catal. A, 1997, 115, 421-429.

[78] H. T. Chung, D. A. Cullen, D. Higgins, B. T. Sneed, E. F. Holby, K. L. More, P. Zelenay, Science, 2017, 357, 479-484.

[79] J. M. Ziegelbauer, T. S. Olson, S. Pylypenko, F. Alamgir, C. Jaye, P. Atanassov, S. Mukerjee, J. Phys. Chem. C, 2008, 112, 8839-8849.

[80] D. X. Liu, B. Wang, H. G. Li, S. F. Huang, M. M. Liu, J. Wang, Q. J. Wang, J. J. Zhang, Y. F. Zhao, Nano Energy, 2019, 58, 277-283.

[81] Y. Zheng, Y. Jiao, Y. H. Zhu, Q. R. Cai, A. Vasileff, L. H. Li, Y. Han, Y. Chen, S. Z. Qiao, J. Am. Chem. Soc., 2017, 139, 3336-3339.

[82] F. Jaouen, J. Herranz, M. Lefevre, J. P. Dodelet, U. Kramm, I. Herrmann, P. Bogdanoff, J. Maruyama, T. Nagaoka, A. Garsuch, J. R. Dahn, T. Olson, S. Pylypenko, P. Atanassov, E. A. Ustinov, ACS Appl. Mater. Interfaces, 2009, 1, 1623-1639.

[83] C. Z. Zhu, S. F. Fu, Q. R. Shi, D. Du, Y. H. Lin, Angew. Chem. Int. Ed., 2017, 56, 13944-13960.

[84] F. Jaouen, E. Proietti, M. Lefèvre, R. Chenitz, J. P. Dodelet, G. Wu, H. T. Chung, C. M. Johnston, P. Zelenay, Energy Environ. Sci., 2010,4, 114-130.

[85] W. O. Haag, R. M. Lago, P. B. Weisz, Nature, 1984, 309, 589-591.

[86] T. F. Jaramillo, K. P. Jörgensen, J. Bonde, J. H. Nielsen, S. Horch, I. Chorkendorff, Science, 2007, 317, 100-102.

[87] S. Shima, O. Pilak, S. Vogt, M. Schick, M. S. Stagni, W. Meyer-Klaucke, E. Warkentin, R. K. Thauer, U. Ermler, Science, 2008, 321, 572-575.

[88] J. K. Nöerskov, T. Bligaard, B. Hvolbaek, F. Abild-Pedersen, I. Chorkendorff, C. H. Christensen, Chem. Soc. Rev., 2008, 37, 2163-2171.

[89] F. Li, Y. F. Bu, G. F. Han, H. J. Noh, S. J. Kim, I. Ahmad, Y. L. Lu, P. Zhang, H. Y. Jeong, Z. P. Fu, Q. Zhong, J. B. Baek, Nat. Commun., 2019, 10, 2623.

[90] Y. Y. Jin, P. P. Hao, J. Ren, Z. Li, Prog. Chem., 2015, 27, 1689-1704.

[91] F. Lin, Y. J. Liu, X. Q. Yu, L. Cheng, A. Singer, O. G. Shpyrko, H. L. Xin, N. Tamura, C. X. Tian, T. C. Weng, X. Q. Yang, Y. S. Meng, D. Nordlund, W. L. Yang, M. M. Doeff, Chem. Rev., 2017, 117, 13123-13186.

[92] G. Hähner, Chem. Soc. Rev., 2006, 35, 1244-1255.

[93] M. K. Chan, W. M. Gong, P. T. R. Rajagopalan, B. Hao, C. M. Tsai, D. H. Pei, Biochemistry, 1997, 36, 13904-13909.

[94] A. Vimont, F. Thibault-Starzyk, M. Daturi. Chem. Soc. Rev., 2010, 39, 4928-4950.

[95] J. Ryczkowski. Catal. Today, 2001, 68, 263-381.

[96] Z. W. Seh, J. Kibsgaard, C. F. Dickens, I. Chorkendorff, J. K. Nörskov, T. F. Jaramillo, Science, 2017, 355, eaad4998.

[97] J. F. Huang, R. Buonsanti, Chem. Mater., 2018, 31, 13-25.

[98] G. B. Wen, D. U. Lee, B. H. Ren, F. M. Hassan, G. P. Jiang, Z. P. Cano, J. Gostick, E. Croiset, Z. Y. Bai, L. Yang, Z. W. Chen, Adv. Energy Mater., 2018, 8, 1802427.

[99] W. J. Zhu, L. Zhang, P. P. Yang, X. X. Chang, H. Dong, A. Li, C. L. Hu, Z. Q. Huang, Z. J. Zhao, J. L. Gong, Small. 2018, 14, 1703314.

[100] J. Rosen, G. S. Hutchings, Q. Lu, S. Rivera, Y. Zhou, D. G. Vlachos, F. Jiao, ACS Catal., 2015, 5, 4293-4299.

[101] Z. Yin, D. F. Gao, S. Y. Yao, B. Zhao, F. Cai, L. L. Lin, P. Tang, P. Zhai, G. X. Wang, D. Ma, X. H. Bao, Nano Energy, 2016, 27, 35-43.

[102] Z. Shi, J. J. Zhang, Z. S. Liu, H. J. Wang, D. P. Wilkinson, Electrochim.
Acta, 2006, 51, 1905-1916.

[103] E. Yeager, Electrochim. Acta, 1984, 29, 1527-1537.

[104] H. S. Wroblowa, Yen-Chi-Pan, G. Razumney, J. Electroanal. Chem., 1976, 69, 195-201.

[105] S. Basu, New Delhi, India, 2007.

[106] W. Xia, A. Mahmood, Z. B. Liang, R. Q. Zou, S. J. Guo, Angew. Chem. Int. Edit., 2016, 55, 2650-2676.

[107] N. A. Anastasijević, S. Štrbac, R. R. Adžić, J. Electroanal. Chem., 1988, 240, 239-252.

[108] Y. Nie, L. Li, Z. D. Wei, Chem. Soc. Rev., 2015, 46, 2168-2201.

[109] M. H. Shao, P. Liu, R. R. Adzic, J. Am. Chem. Soc., 2006, 128, 7408-7409.

[110] J. K. Nörskov, J. Rossmeisl, A. Logadottir, L. Lindqvist, J. R. Kitchin, T. Bligaard, H. Jónsson, J. Phys. Chem. B, 2004, 108, 17886-17892.

[111] Y. Zheng, A. Vasileff, X. L. Zhou, Y. Jiao, M. Jaroniec, S. Z. Qiao, J. Am. Chem. Soc., 2019, 141, 7646-7659.

[112] J. L. Liu, C. X. Guo, A. Vasileff, S. Z. Qiao, Smallmthods, 2017, 1 , 1600006.

[113] M. G. Kibria, J. P. Edwards, C. M. Gabardo, C. T. Dinh, A. Seifitokaldani, D. Sinton, E. H. Sargent, Adv. Mater., 2019, 1807166.

[114] M. J. Cheng, E. L. Clark, H. H. Pham, A. T. Bell, M. Head-Gordon, ACS Catal., 2016, 6, 7769-7777.

[115] J. Bockris, Int. J. Hydrogen Energy, 2002, 27, 731-740.

[116] C. G. Morales-Guio, L. A. Stern, X. L. Hu, Chem. Soc. Rev., 2014, 43, 6555-6569.

[117] Y. Jiao, Y. Zheng, M. Jaroniec, S. Z. Qiao, Chem. Soc. Rev., 2015, 44, 2060-2086.

[118] J. Li, G. F. Zheng, Adv. Sci., 2017, 4, 1600380-1600394.

[119] M. Kuang, G. F. Zheng, Small, 2016, 12, 5656-5675.

[120] J. Li, Y. C. Wang, T. Zhou, H. Zhang, X. H. Sun, J. Tang, L. J. Zhang, A. M. Al-Enizi, Z. Q. Yang, G. F. Zheng, J. Am. Chem. Soc., 2015, 137, 14305-14312.

[121] M. Kitano, Y. Inoue, Y. Yamazaki, F. Hayashi, S. Kanbara, S. Matsuishi, T. Yokoyama, S. W. Kim, M. Hara, H. Hosono, Nat. Chem., 2012, 4, 934-940.

[122] R. F. Service, Science, 2014, 345, 610-610.

[123] Y. Abghoui, A. L. Garden, J. G. Howalt, T. Vegge, E. Skúlason, ACS Catal., 2015, 6, 635-646.

[124] H. Daims, E. V. Lebedeva, P. Pjevac, P. Han, C. Herbold, M. Albertsen, N. Jehmlich, M. Palatinszky, J. Vierheilig, A. Bulaev, R. H. Kirkegaard, M. V. Bergen, T. Rattei, B. Bendinger, P. H. Nielsen, M. Wagner, Nature, 2015, 528, 504-509.

[125] A. N. Rollinson, J. Jones, V. Dupont, M. V. Twigg, Energy Environ. Sci., 2011, 4, 1216-1224.

[126] K. H. Liu, H. X. Zhong, S. J. Li, Y. X. Duan, M. M. Shi, X. B. Zhang, J. M. Yan, Q. Jiang, Prog. Mater. Sci., 2018, 92, 64-111.

[127] D. Bao, Q. Zhang, F. L. Meng, H. X. Zhong, M. M. Shi, Y. Zhang, J. M. Yan, Q. Jiang, X. B. Zhang, Adv. Mater., 2017, 29, 1604799.

[128] K. Liu, A. Q. Wang, T. Zhang, ACS Catal., 2012, 2, 1165-1178.

[129] Q. C. Wang, Y. P. Lei, D. S. Wang, Y. D. Li, Energy Environ. Sci., 2019, 12, 1730-1750.

[130] L. M. Molina, M. D. Rasmussen, B. Hammer, J. Chem. Phys., 2004, 120, 7673-7680.

[131] L. Li, Y. Gao, H. Li, Y. Zhao, Y. Pei, Z. F. Chen, X. C. Zeng, J. Am. Chem. Soc., 2013, 135, 19336-19346.

[132] W. An, P. Liu, Phys. Chem. Chem. Phys., 2016, 18, 30899-30902.

[133] Y. P. Lei, Q. Shi, C. Han, B. Wang, N. Wu, H. Wang, Y. D. Wang, Nano Res., 2016, 8, 2498-2509.

[134] L. Zhao, Q. C. Wang, X. Q. Zhang, C. Deng, Z. H. Li, Y. P. Lei, M. F. Zhu, ACS Appl. Mater. Inter., 2018, 10, 35888-35895.

[135] T. Ioroi, Z. Siroma, S. I. Yamazaki, K. Yasuda, Adv. Energy Mater., 
2019, 9, 1801284.

[136] C. K. Dyer, J. Power Sources, 2002, 106, 31-34.

[137] H. Shan, W. P. Gao, Y. L. Xiong, F. L. Shi, Y. C. Yan, Y. L. Ma, W. Shang, P. Tao, C. Y. Song, T. Deng, H. Zhang, D. Yang, X. Q. Pan, J. B. Wu, Nat. Commun., 2018, 9, 1011.

[138] Z. Y. Chen, Q. C. Wang, X. B. Zhang, Y. P. Lei, W. Hu, Y. Luo, Y. B. Wang, Sci. Bull., 2018, 9, 548-555.

[139] Q. C. Wang, Y. P. Lei, Y. G. Zhu, H. Wang, J. Z. Feng, G. Y. Ma, Y. D.
Wang, Y. J. Li, B. Nan, Q. G. Feng, Z. G. Lu, H. Yu, ACS Appl. Mater. Inter., 2018, 10, 29448-29456.

[140] Q. C. Wang, Y. J. Ji, Y. P. Lei, Y. B. Wang, Y. D. Wang, Y. Y. Li, S. Y. Wang, ACS Energy Lett., 2018, 3, 1183-1191.

[141] P. Tan, B. Chen, H. R. Xu, H. C. Zhang, W. Z. Cai, M. Ni, M. L. Liu, Z. P. Shao, Energy Environ. Sci., 2017, 10, 2056-2080.

[142] B. Han, R. Lang, B. T. Qiao, A. Q. Wang, T. Zhang, Chin. J. Catal., 2017, 9, 1498-1507.

\title{
双原子催化剂: 制备、表征和应用

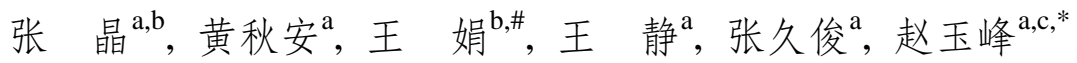 \\ a 上海大学可持续能源研究院/理学院, 上海200444 \\ b西安建筑科技大学机电工程学院, 陕西省纳米材料与技术重点实验室, 陕西西安710055 \\ ${ }^{\mathrm{C}}$ 燕山大学应用化学重点实验室, 河北秦皇岛066004
}

\begin{abstract}
摘要: 发展可持续和清洁的电化学能源转化技术是应对能源短缺和环境污染挑战的关键一步, 燃料电池、电解电池和金属 空气电池作为清洁能源储存和转换装置目前得到广泛应用推广, 这些装置依靠电催化反应以及电极材料上发生的电荷转 移过程来转换电能和化学能. 而电催化剂是该类装置电极材料的核心部件, 电催化反应的热力学和动力学过程与电催化 剂的物理性质和化学状态密切相关. 因此探索和开发性能优良、成本低廉的新型电催化剂, 将进一步促进这些能源转化技 术的商业化应用.

单原子催化剂(SACs)以其暴露的活性位点、高选择性和最大限度地原子利用率而受到人们的广泛关注. 然而, 随着单 原子表面自由能的增加, 粒子在制备和催化过程中的聚集, 催化活性位点的降低和催化剂负荷的相对较低, 严重制约了 SACs的发展和应用. 考虑到SACs的缺点, 为了进一步增加单原子活性位点的数量和负载, 双原子催化剂(DACs)作为SACs 家族成员的扩展近年来逐渐兴起, 且两种金属原子(同核/异核)在DACs中的协同作用显著提高了催化剂的催化活性.

本文基于当前最新的研究工作对比了同核/异核DACs的不同优势, 列举了一系列包括原子层沉积法、湿化学吸附法以 及高温热处理法等方法用于制备性能优异的DACs, 其中高温热处理法因应用广泛被重点强调. 同时, 本文也对DACs的表 征和识别手段进行了重点概括, 包含XANES, EXAFS, IR, DFT等; 详细概括和对比了当前DACs在电化学方面的主要应用, 如氧还原反应(ORR)和二氧化碳还原反应.

目前, DACs作为一个新兴的研究领域, 由于其金属原子负载量高、活性位点比SACs更为灵活, 已经在电催化领域取得 了快速的发展. 相对于同核DACs, 原则上不同的两个金属原子会组成更多的异核DACs, 因此, 对于性能优异的异核DACs 还有更多的可能性值得深入探索. 可以预见, DACs的发展将弥补SACs的不足, 在电化学能源的转换和储存方面发挥全面 的优势; 借助于异核DACs中不同的两个金属原子的多样性, 探索以过渡金属为主的DACs, 将会为节约贵金属资源及环境 保护带来巨大贡献, 进一步设计和优化DACs, 有利于燃料电池和金属-空气电池创造出更大的经济效益和社会效益. 因此, 我们相信DACs的发展将成为材料研究的一个新前沿, 并为合成更多的高效应用催化剂开辟一条新的途径.
\end{abstract}

关键词: 双原子催化剂; 同核; 异核; 电化学; 能源转换和储存

收稿日期: 2019-10-12. 接受日期: 2019-11-23. 出版日期: 2020-05-05.

*通讯联系人. 电子信箱: yufengzhao@shu.edu.cn

\#通讯联系人. 电子信箱: juanwang168@gmail.com

基金来源：国家自然科学基金(51774251); 河北杰出青年科学基金(B2017203313); 河北省百名创新人才经费(SLRC2017057); 特 种电源国家重点实验室开放基金(SKL-ACPS-C-11); 河北省人才工程培养经费(A201802001).

本文的电子版全文由Elsevier出版社在ScienceDirect上出版(http://www.sciencedirect.com/science/journal/18722067). 